\title{
Fibrosis in diabetes complications: Pathogenic mechanisms and circulating and urinary markers
}

\author{
Camelia R Ban \\ Stephen M Twigg \\ Discipline of Medicine and \\ Department of Endocrinology, The \\ University of Sydney and Royal Prince \\ Alfred Hospital, Sydney, New South \\ Wales, 2006, Australia
}

\begin{abstract}
Diabetes mellitus is characterized by a lack of insulin causing elevated blood glucose, often with associated insulin resistance. Over time, especially in genetically susceptible individuals, such chronic hyperglycemia can cause tissue injury. One pathological response to tissue injury is the development of fibrosis, which involves predominant extracellular matrix (ECM) accumulation. The main factors that regulate ECM in diabetes are thought to be pro-sclerotic cytokines and protease/anti-protease systems. This review will examine the key markers and regulators of tissue fibrosis in diabetes and whether their levels in biological fluids may have clinical utility.
\end{abstract}

Keywords: diabetic complications, extracellular matrix, markers

\section{Introduction}

Fibrosis is characterized by extracellular matrix (ECM) accumulation and often by a change in the quality of the ECM, as well as angiogenesis. It is a common pathological response to tissue insults such as hyperglycemia, dyslipidemia, and hypertension. This review will examine the extent and type of tissue fibrosis that occurs in experimental and human diabetes, with an emphasis on potential circulating and urinary predictors and markers of fibrosis in human diabetes. While the pathogenesis and nature of end-organ complications in type 1 and type 2 diabetes are similar, especially in glucose-dependent aspects of microvascular disease, where possible throughout the text the type of diabetes is referenced.

\section{Fibrosis in tissues affected by diabetic complications Microvessels}

Long-standing diabetes leads to both structural and functional anomalies in the vasculature (Zimmet 2000; Khan et al 2003) which characterize micro- and macrovascular diabetic complications: retinopathy, nephropathy, cardiomyopathy, peripheral vascular disease, cerebrovascular disorders, and atherosclerosis. Firstly described by Siperstein and colleagues (1968), extracellular matrix (ECM) alterations and basement membrane (BM) thickening have been documented as structural hallmarks in all target organs of diabetic complications (Brownlee et al 1979; Tsilibary 2003). The morphological and biochemical disturbances of the ECM are directly related to a loss of function in target organs (Farquhar et al 1972; Scheinman et al 1974; Ikeda et al 1991; Makino et al 1993). ECM comprises an insoluble network of collagens, elastins, structural glycoproteins, proteoglycans-hyaluronans and integrins, which provide not only mechanical support for the cells, but also mediate complex interactions between the cells or between cells and the ECM of vascular tissues (Hayden et al 2005). EC matrices differ qualitatively and quantitatively from tissue to tissue and within various organs. 


\section{Diabetic retinopathy}

Expansion of ECM that occurs in diabetic complications can be due to increased synthesis of matrix proteins and/or an inhibition of ECM degradation. With respect to the increased synthesis of matrix, proteins that are normally present in these structures or proteins that are not present in normal tissue, or both, may be induced. Thus, collagen types I and IV as well as laminin and fibronectin are normal constituents of normal retinal vessels from large thick-walled vessels down to microvessels less than 10 microns in diameter, whilst types III and V collagen were seen to stain primarily the walls of the larger vessels. A preclinical hallmark of early diabetic retinopathy (DR) is the thickening of the capillary basement membrane (BM) resulting from increased production and/or decreased breakdown of collagen IV, laminin, fibronectin, and other proteins (Roy et al 1990; Ljubimov et al 1996; Spirin et al 1999; Lorenzi et al 2001). In proliferative diabetic retinopathy (PDR), the BM of the new vessels and the epiretinal membranes show significantly increased amounts of types VI, VIII, XII, and XIV collagen, as well as perlecan, bamacan (Ljubimov et al 1996), fibronectin, tenascin (Ioachim et al 2005), and vimentin (Hosoda et al 1993). While not present in normal retina (Jerdan et al 1986), type II collagen was found in epiretinal membranes (ERM) (Hosoda et al 1993). A positive relationship was found between fibronectin expression and ERM proliferative activity (Ioachim et al 2005). Downregulation of fibronectin synthesis could partially prevent retinal BM thickening along with a reduction of pericyte loss and acellular capillaries in animal model (Roy et al 2003).

\section{Diabetic renal disease}

Type IV collagen collagen, fibronectin and laminin, which are normal constituents of the mesangium and glomerular basement membrane (GBM), are increased in diabetic kidney disease (Kim et al 1991; Makino et al 1993; Kiryu et al 1994; Zhu et al 1994; Yagame et al 1995; Razzaque et al 1997; Moriya et al 2001). Accelerated matrix deposition (type IV collagen) can be present even in early stages of diabetic renal disease (microalbuminuria stages) in experimental models (Liu $\mathrm{Y}$ et al 2007). In diabetic diffuse glomerulosclerosis deposition of collagen IV, V, laminin, and fibronectin is increased in the mesangial matrix and glomerular basement membranes (Nerlich et al 1991; Tsilibary 2003), whilst in nodular glomerulosclerosis normal BM components are decreased or absent (Olgemoller et al 1993). Expressed only under pathological conditions, type I and III collagen appears in the late stages of glomerulosclerosis (Glick et al 1992;
Makino et al 1994; Razzaque et al 1994; Makino et al 1995; Stokes et al 2000; Schaefer et al 2001), and are associated with the development of Kimmelstiel-Wilson nodules rather than with the diffuse expansion of the mesangial matrix, which occurs in the early and moderately advanced stages of the disease. Decreased levels of proteoglycans (heparin sulphate, perlecan) found in diabetic kidney in the mesangial matrix, GBM, the endothelial and epithelial BM, and renal tubular cells have also been assigned a role in the development of diabetic micro- and macroalbuminuria (Schaefer et al 2001). Interestingly, a substantial subset of type 2 diabetic patients, despite the presence of microalbuminuria or proteinuria, have normal glomerular structure with or without tubulointerstitial and/or arteriolar abnormalities (Fioretto et al 2007).

\section{Diabetic cardiomyopathy}

Both types I and III collagen are present in normal and diseased myocardial tissue. Type I collagen is predominant in the myocardium, but type III is more specific to cardiac tissue (Bishop et al 1995; Zannad et al 2000; D’Armiento 2002). Myocardial biopsies from diabetic subjects revealed a significantly higher proportion of type III collagen compared with their nondiabetic counterparts, while the proportion of collagen type I did not differ between the groups (Shimizu et al 1993). Responsible for the increased left ventricle (LV) mass (van Hoeven et al 1990), diffuse myocardial fibrosis has a distribution in both interstitium and perivascular sites (Regan et al 1977; Nunoda et al 1985; Genda et al 1986; Das et al 1987; van Hoeven and Factor 1990). Extensive myocyte necrosis and replacement of contractile fibers by connective tissue are likely to account for depressed cardiac performance, at least in advanced stages of diabetic cardiomyopathy (Factor et al 1980). It appears that hypertrophy of myocardial cells and myocardial interstitial fibrosis may be present even in mild hyperglycemia in diabetes (Nunoda et al 1985).

\section{Larger arteries}

In animal models of type 2 diabetes it has been found that increased intimal proliferation and medial thickness as well as ECM deposition occur in vessels such as mesenteric arteries and aorta (Song and Ergul 2006). Vascular remodeling and hypertrophy associated with augmented expression of dedifferentiation markers of vascular smooth muscle cells also occur in larger vessels like aorta (Vranes et al 1999). Fibronectin expression varied in different reports in large vessels (Fukuda et al 2005). Proteoglycans (PGs) such 
as versican, biglycan, and decorin have been involved in diabetic nephropathy pathogenesis (Schaefer et al 2001). PGs accumulate in developing atherosclerotic and restenotic lesions, and thus contribute to plaque burden and influence cellular and extracellular events associated with the pathogenesis of vascular lesions, such as migration and proliferation, lipid metabolism and retention, and thrombosis (Shirk et al 2000; Edwards et al 2004; Nakashima et al 2007; Tran et al 2007).

\section{Nonalcoholic fatty liver disease}

Type 2 diabetic patients also have an increased risk for developing chronic liver disease. Nonalcoholic fatty liver disease (NAFLD) represents a spectrum of conditions characterized histologically by excessive accumulation of hepatic fat in the absence of alcohol consumption. Obesity, type 2 diabetes, dyslipidemia, and hypertension contribute to the risk for liver disease and to disease progression. Two main histological patterns of NAFLD are described: fatty liver alone and nonalcoholic steatohepatitis (NASH). NASH is an increasingly recognized cause of liver-related morbidity and mortality (Angulo 2002; Sanyal 2002; Charlton 2004), with about a quarter of patients progressing to serious liver sequelae, including end-stage liver disease and hepatocellular carcinoma (Bugianesi et al 2002; Ratziu et al 2002). Those at highest risk include patients with significant hepatic necroinflammation and fibrosis (Ratziu et al 2000; Sanyal 2002).
Unlike other vascular beds, the normal hepatic sinusoids have no BM to become thickened. Sinusoidal (perisinusoidal) fibrosis with formation of BMs occurs in a variety of liver diseases, including chronic viral hepatitis, alcoholic hepatitis and NASH. In those diseases, the fibrosis is a result of the activation of the hepatic stellate cells with a phenotypic transition to collagen-producing myofibroblasts. Activated hepatic stellate cells are involved in the ECM degradation and remodeling that occur with fibrogenesis (Sugimoto et al 2005).

\section{Effects of diabetes on regulators of ECM turnover}

\section{Metabolic and hemodynamic induction of fibrosis by hyperglycemia}

Chronic hyperglycemia is a main factor in the onset of microvascular diabetic complications in both type 1 and 2 diabetes, as strict glycemic control reduces end-organ complication incidence and rate of progression (The Diabetes Control and Complications Trial Research Group 1993; UK Prospective Diabetes Study Group 1998). This pathogenesis is shown schematically in Figure 1. Specific biochemical pathways linking hyperglycemia to microvascular changes have been proposed: increased glucose flux through the polyol pathway (Greene et al 1987), nonenzymatic glycation of proteins (Brownlee et al 1988), glucose autooxidation, and oxidative stress (Hunt et al 1990), hyperglycemic pseudohypoxia

Initial insult(s)

(genetic and environmental)

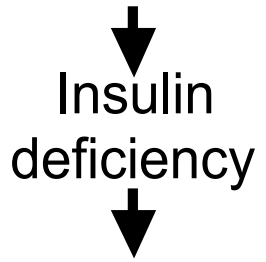

Elevated blood glucose levels

(to diabetic range)

$\downarrow$

Cell and tissue injury

$\downarrow$

Diabetes end-organ complications

Figure I The linear pathway leading from insulin deficiency, through hyperglycemia to diabetes complications. 
(Williamson et al 1993), enhanced activation of protein kinase C isoforms (Lee et al 1989; DeRubertis and Craven 1994), and alteration in cell signaling pathways (Brownlee 2001; Sheetz et al 2002). As described in subsequent sections, experimental data support causative roles for hyperglycemia and these downstream biochemical pathways in causing alterations in ECM turn-over (Fukui et al 1992; Nahman et al 1992; Roy et al 1994; Wahab et al 1996). Hyperglycemia can work through both metabolic and hemodynamic pathways to change growth factors and ECM turn-over. This is shown schematically in Figure 2.

\section{Advanced glycation end-products (AGEs)}

Hyperglycemia is responsible for the presence of high levels of nonenzymatically produced AGEs in patients with diabetes (Goldin et al 2006). AGEs are able to stimulate directly the production of ECM. Nonenzymatic glycosylation of collagens produces cross-linkages and hence may produce physical alterations in the properties of the ECM. AGEs modification of matrix proteins is able to disrupt matrixmatrix and matrix-cell interactions, contributing to their profibrotic action. In addition, AGEs significantly interact with the renin-angiotensin system. AGEs play important roles in cell signaling by interacting with specific receptors, receptor for advanced glycation end products (RAGE), that link to the activation of adhesion molecules, proinflammatory cytokines and growth factors, thus contributing to the pathogenesis of diabetic complications (Mason et al 2003; McLennan et al 2004). AGEs have extracellular effects, such as protein cross-linking, that appear to inhibit ECM degradation and promote the expansion of the glomerular mesangial matrix and BM in diabetic kidney disease. Drugs that either inhibit the formation of AGE or break AGEinduced cross-links have been shown to be renoprotective in experimental models of diabetic nephropathy (Forbes et al 2002).

\section{The renin-angiotensin-aldosterone system}

The renin-angiotensin-aldosterone system (RAAS) is an important contributor to the pathogenesis of diabetic microand macrovascular complications by inducing various tissue responses, such as vasoconstriction, inflammation, oxidative stress, cell hypertrophy and proliferation, angiogenesis and fibrosis. RAAS effects can be locally generated in many organs (Paul et al 1993; Morgan et al 1994; Wagner et al 1996; Engeli et al 1999; Bataller et al 2003).

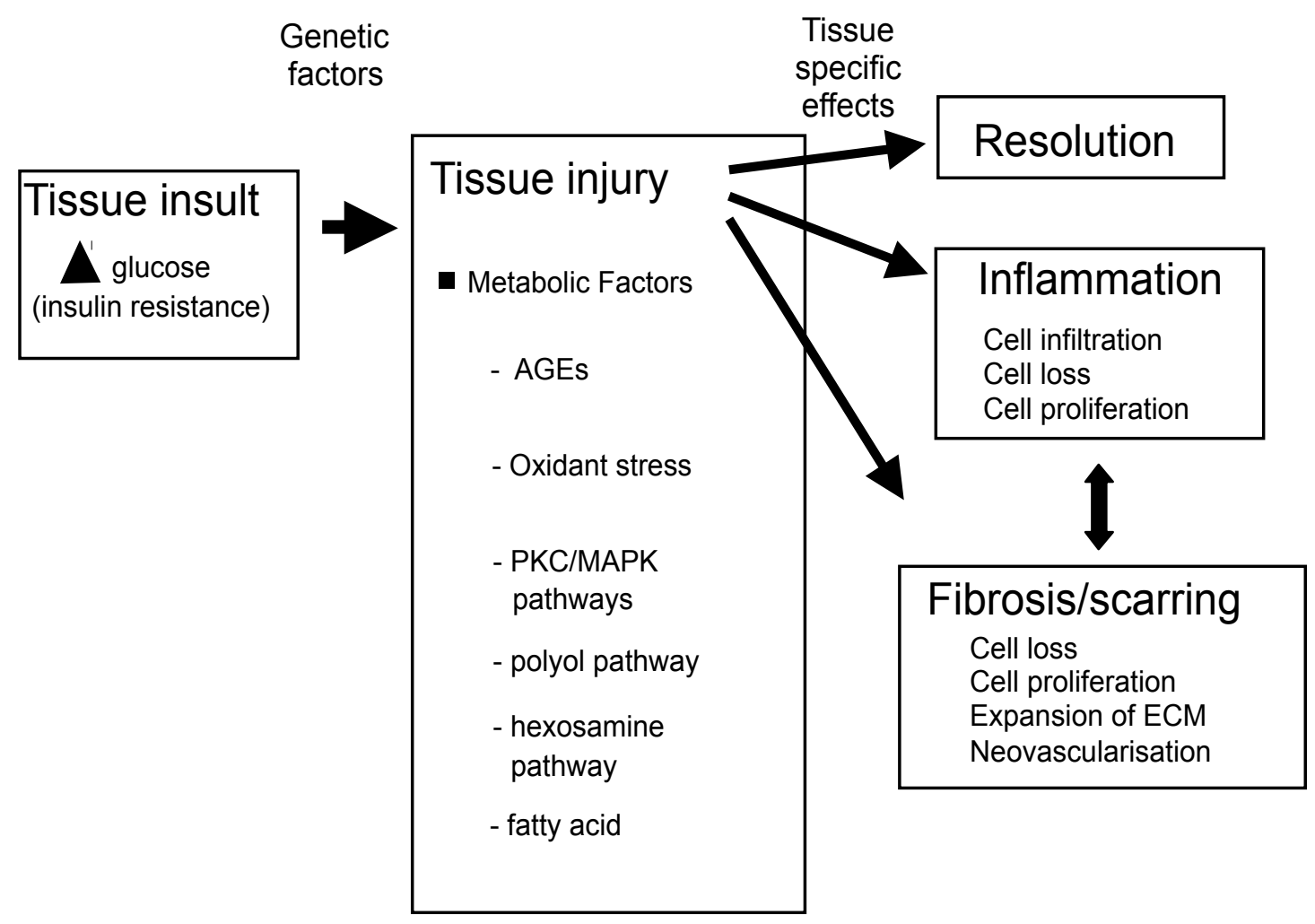

Figure 2 Schematic diagram indicating how hemodynamic and metabolic factors, and growth factors, can network to cause tissue damage. Inflammation and fibrosis occur variably in tissue at different stages of diabetes complications. 
Angiotensin II (Ang II), the main physiological effector molecule of RAAS, mediates fibrosis by stimulating the synthesis of ECM components (Kagami et al 1994; GomezGarre et al 1996; Brilla et al 1997) apoptosis/proliferation (Efrati et al 2007), infiltration of inflammatory cells, and the release of inflammatory cytokines and growth factors such as transforming growth factor (TGF)- $\beta 1$ (Wu et al 1997), monocyte chemoattractant protein (MCP)-1 (Ruiz-Ortega et al 1998), vascular endothelial growth factor (VEGF) (Otani et al 2000), platelet derived growth factor (PDGF) (Naftilan et al 1989), and connective tissue growth factor (CTGF) (Ruperez et al 2003a; Finckenberg et al 2003). Ang II is up-regulated under the diabetic conditions (Singh et al 1999) and exerts its deleterious effects through the angiotensin type I receptor (AT1R). RAS blocking with either angiotensin converting enzyme inhibitors (ACEI) or angiotensin type 1 receptor blockers (ARB) has clearly demonstrated positive outcomes on diabetic complications, with benefits beyond those derived from lowering blood pressure. Thus ACEI and/ or ARB treatment can slow the progression of diabetic renal disease (The EUCLID Study Group 1997; Heart Outcomes Prevention Evaluation Study Investigators 2000), decrease cardiovascular events (Heart Outcomes Prevention Evaluation Study Investigators 2000), may decrease retinopathy in T1DM (Chaturvedi et al 1998) and improves diastolic dysfunction in diabetic patients (Kawasaki et al 2007).

Another component of the RAAS, aldosterone, plays also a role in the development of hypertension, endothelial dysfunction, vascular structure damage, proteinuria, myocardial fibrosis, collagen synthesis (Cha et al 2005). Spironolactone, an aldosterone antagonist, associated to ACEI and/or ARB treatment may offer additional renoprotection in diabetic nephropathy (Sato et al 2003; Schjoedt et al 2006; van den Meiracker et al 2006).

\section{Growth factors}

Under normal circumstances ECM undergoes continuous synthesis and degradation and ECM turn-over is a requisite for normal structure and function of organs and tissues (Tyagi et al 1995). ECM turn-over is characterized by a balance between matrix formation and matrix degradation. Factors that regulate ECM formation include multiple forms of growth factor such as such as TGF- $\beta$ (McClain et al 1992; Kolm et al 1996; Riser et al 1998), CTGF (Twigg and Cooper 2004; Twigg et al 2001; McLennan et al 2004; Paradis et al 2001; Liu X et al 2007), and insulin-like growth factor I (IGF-I), fibroblast growth factor (FGF), epidermal growth factor (EGF) and PDGF, (Lembach 1976; Tseng et al
1982; Dresow et al 1984; Roberts et al 1986; Qi et al 2005). Enzymes responsible for ECM degradation and remodeling include the matrix metalloproteinases (MMPs) (McLennan et al 1998, 2000; Death et al 2003), and serine proteases (Geiger et al 1988), as well as their respective tissue inhibitors, the TIMPs (Nakamura et al 1994; Shankland et al 1996; Gomez et al 1997), and PAI-1 (Fisher et al 1997; McLennan et al 2000). These regulators of ECM will now be explored in detail in diabetic complications.

The important role of growth factors in the pathogenesis of diabetic long-term complications was suggested by their increased concentrations in target tissues (Yamamoto et al 1993; Tikellis et al 2004; Roestenberg et al 2006; Umezono et al 2006). In diabetic nephropathy, IGF-I seems to be implicated in the earlier stages of the disease, while TGF- $\beta$ and CTGF are involved both in the early and later stages, being responsible, at least in part, for ECM accumulation (Park et al 1997; Gilbert et al 1998; Riser et al 2000). VEGF and FGF play a pivotal role both in nonproliferative and proliferative retinopathy (Wells et al 1996; Mathews et al 1997).

Figure 3 indicates the main growth factors involved in diabetic complications, based on tissue levels measured in human and animal diabetes, and also on intervention studies mainly in animals. An excess of growth factor is implicated in tissues where fibrosis predominates, whereas a lack of growth factors occurs in diabetic neuropathy and wound healing.

\section{TGF- $\beta$}

TGF- $\beta$ is generally accepted to be the main pro-fibrotic factor in diabetic nephropathy. Several lines of experimental and clinical evidence support a major role for TGF- $\beta$ in development of glomerulosclerosis and interstitial fibrosis in diabetes. Diabetic environment up-regulated TGF- $\beta 1$ expression and bioactivity in glomerular mesangial cells and proximal tubule cells (Ziyadeh et al 1994, 1998; Sharma et al 1995). With the development of incipient diabetic nephropathy TGF- $\beta$ mRNA increased in mesangial cells, podocytes and tubular epithelial cells. Progression to manifest diabetic nephropathy was associated with further increase in TGF- $\beta$ mRNA, especially in the glomeruli (Wahab et al 2005). The kidney of a diabetic patient actually elaborates TGF- $\beta 1$ protein into the circulation whereas the kidney of a nondiabetic subject extracts TGF- $\beta 1$ from the circulation (Sharma et al 1997). Inhibition of TGF- $\beta 1$ with neutralizing antibodies prevented glomerular enlargement, and attenuated the excess matrix expression by reducing type IV collagen and fibronectin mRNA (Sharma et al 1996; Ziyadeh et al 2000). 
Growth factor excess Growth factor deficiency

- Diabetic nephropathy - Diabetic wounds

- TGF- $\beta$, IGF-1, VEGF, CTGF, PDGF, EGF, bFGF

- PDGF, EGF, TGF- $\beta$, VEGF, CTGF, bFGF

- Diabetic retinopathy

- VEGF, IGF-1, CTGF, angiopoetin-1, EGF

- Atherosclerosis - TNF- $\alpha$, TGF- $\beta$
- Diabetic neuropathy

- IGF-1, NGF (nerve growth factor)

- Diabetic cardiomyopathy - VEGF

Figure 3 The major growth factors implicated in diabetes complications. The prosclerotic ones involved in human diabetic fibrosis are currently thought to be TGF- $\beta$ and CTGF.

Up-regulation of TGF- $\beta$ protein was demonstrated in the myocardium of rodents with diabetic cardiomyopathy. ARB treatment reduced its expression and decreased cardiac fibrosis (Westermann et al 2007). TGF- $\beta$ is also involved in liver fibrosis (Roth et al 1998), by activating the hepatic stellate cells and inducing apoptosis of hepatocytes in liver injury (Oberhammer et al 1992). However, due to its important anti-proliferative and anti-inflammatory effects, TGF- $\beta$ is not a suitable target for therapeutic intervention.

\section{CTGF}

CTGF is another prominent growth factor in the pathogenesis of diabetic nephropathy. High glucose conditions, TGF- $\beta$, AGEs, RAS, TNF- $\alpha$, mechanical strain or CTGF itself promote CTGF expression by mesangial cells (Wahab et al 1996; Murphy et al 1999; Riser et al 2000; Twigg et al 2001, 2002a; Cooker et al 2007; Hughes et al 2007). CTGF can also be produced by podocytes (Roestenberg et al 2006), parietal epithelial cells (Umezono et al 2006) and proximal tubular cells (Wang et al 2001; Roestenberg et al 2006). In experimental type 1 and type 2 diabetes CTGF mRNA and protein was up-regulated in various organs: kidney, heart, liver, retina (Roestenberg et al 2006). Glomerular CTGF mRNA levels were found to be upregulated in diabetic patients with microalbuminuria as well as in overt nephropathy (Umezono et al 2006). In addition, CTGF mRNA levels were found to correlate with the degree of albuminuria (Adler et al 2001). We have recently found that renal tubular CTGF protein by renal biopsy at 5 years predicts albuminuria at 10 years, in a diabetic baboon model of type 1 diabetes (Thomson et al 2007). The role of CTGF in DN pathogenesis in both type 1 and type 2 diabetes has been confirmed by a recent study showing that a CTGF antisense oligonucleotide may attenuate progression of nephropathy in mice (Guha et al 2007). CTGF overexpression in podocytes was critically involved in diabetes-related GBM thickening (Roestenberg et al 2006). However, a site-specific downregulation of CTGF accompanied by a reduced VEGF-A mRNA in glomeruli from diabetic patients can be evidenced in $\mathrm{DN}$ and is a result of podocyte loss (Baelde et al 2007).

Relative abundance of myocardial mRNA for CTGF compared with brain natriuretic peptide (BNP) was positively correlated with diastolic dysfunction, myocardial fibrosis area, and procollagen type 1 mRNA expression in a rat pressure overload cardiac hypertrophy model. Exogenous BNP prevented the production of CTGF in cardiac myocytes (Koitabashi et al 2007).

CTGF has been shown to be up-regulated in the retina of diabetic rats (Tikellis et al 2004). It appears that in diabetes CTGF expression shifts from microglia to microvascular pericytes (Kuiper et al 2004). CTGF was also expressed in endothelial cells and myofibroblast in PDR membranes, and in myofibroblast in proliferative vitreoretinal membranes (Abu El-Asrar et al 2007). CTGF is overexpressed in pericytes in the human diabetic retina, irrespective of changes related to clinical DR like vascular leakage (Kuiper et al 2004). Overexpression of CTGF in cultured human aortic smooth muscle cells, a cell type closely related to pericytes and mesangial cells, induced apoptosis by activating caspase 3 (Hishikawa et al 1999). 
In fibrotic liver, CTGF mRNA and protein are produced by hepatocytes, fibroblasts, myofibroblasts, hepatic stellate cells (HSCs), endothelial cells, and bile duct epithelial cells (Rachfal et al 2003). Interestingly, whilst in HSCs CTGF was only marginally stimulated by TGF- $\beta$, in cultured hepatocytes it was strongly upregulated by TGF- $\beta$ (Gressner et al 2007). CTGF could be reduced in liver by antisense RNA of CTGF recombinant or slicing through siRNA, which decreased activation of HSCs, prevented the upregulation of CTGF and TGF-beta1 gene expression and inhibited accumulation of connective tissue proteins in the liver (George et al 2007; Lu et al 2007).

Once induced, CTGF can up-regulate its own gene expression (Riser et al 2000; Twigg et al 2001; Wahab et al 2001). It is also able to initiate changes in ECM composition: it increased expression of fibronectin (Wahab et al 2001; Ruperez et al 2003a; Weston et al 2003) and enhanced fibronectin assembly into an insoluble matrix (Weston et al 2003), increased in type IV (Zhou et al 2004), type III (Lam et al 2004) and type I collagen production (Gore-Hyer et al 2002), and up-regulated integrins on the cell surface, facilitating the deposition and assembly of ECM proteins (Weston et al 2003). Furthermore, CTGF caused induction of plasminogen activator inhibitor-1 (Wahab et al 2001), rearrangement of the actin cytoskeleton (Crean et al 2002) and an increase in TIMP-1 with subsequent decrease in matrix degradation (McLennan et al 2004). CTGF also exerted a strong chemotactic effect on peripheral blood mononuclear cells in vitro (Cicha et al 2005), which may then contribute to tissue inflammation and late fibrosis (Frazier et al 1996).

CTGF has been described as a downstream mediator of TGF- $\beta$ in the fibrotic process (Igarashi et al 1993; Grotendorst et al 1996; Duncan et al 1999; Weston et al 2003; Kobayashi et al 2005). TGF- $\beta 1$-induced effects can be blocked by CTGF antisense oligonucleotides (Duncan et al 1999; Abdel-Wahab et al 2002; Weston et al 2003). However, CTGF can also exert its pro-fibrotic effects via TGF- $\beta 1$-independent pathways (Murphy et al 1999; Blom et al 2001; Twigg et al 2001; McLennan et al 2004; Chaqour et al 2006) as seen for induction of CTGF by AGEs which is TGF- $\beta$ independent (Twigg et al 2001). Glucose-induced collagen production was reduced by CTGF anti-sense nucleotide (Wahab et al 2001; Abdel-Wahab et al 2002; Ruperez et al 2003a; Weston et al 2003; Guha et al 2007), ACEI or ARB (Ruiz-Ortega et al 1995; Wu et al 1997; Border et al 1998; Ruperez et al 2003b; Tsutsui et al 2007), or by treatment with an AGE inhibitor (Twigg et al 2002b; Candido et al 2003). CTGF can interact with, and influence the signaling of IGF-I (Lam et al 2003), VEGF (Brigstock 2002), TGF- $\beta$ (Grotendorst et al 1996) and bone morphogenic proteins (BMPs) (Abreu et al 2002). Moreover, CTGF can be cleaved by metalloproteases (MMPs) and other proteases (Hashimoto et al 2002).

\section{PDGF- $\beta$}

PDGF- $\beta$ is involved in structural alterations at the glomerular level. It seems that high glucose induces an early activation of a PDGF loop that in turn causes an increase of TGF- $\beta 1$ gene expression, thus modulating both human mesangial cell proliferation and mesangial matrix production (Di Paolo et al 1996).

\section{VEGF}

VEGF appears to be another mediator for these early and late vascular changes. Neutralizing antibodies directed against VEGF blocked vascular permeability and blood flow changes induced by elevated tissue glucose and sorbitol levels in a dosage-dependent manner (de Vriese et al 2001). VEGF signaling affected GBM thickening, slit pore density, and nephrin quantity, all of which were associated with the extent of diabetic albuminuria. These effects could be blocked by a VEGF receptor inhibition (Sung et al 2006).

\section{FGF}

FGF is secreted by fibroblasts, macrophages and in particular endothelial cells (EC) in response to tissue injury and is important in promotion of neovascularization. Produced and stored in epiretinal membranes (Hueber et al 1996; Schneeberger et al 1997), FGF is a potent endothelial cell mitogen that has been proposed to play a role in proliferative diabetic retinopathy and other neovascular processes (Hanneken et al 1991).

\section{Protease systems and their regulators The MMP system}

Metalloproteinases (MMPs) are a family of zinc-dependent enzymes with the combined ability to digest all ECM proteines: native and partially degraded fibrillar collagens, basement membrane collagens, proteoglycans, elastin, fibronectin. The gelatinase (MMP-2 and MMP-9) are two proteinases primarily responsible for breaking down type IV collagen from the BMs. These are produced by multiple vascular cell types, such as pericytes, podocytes, vascular smooth muscles cells, renal mesangial cells, fibroblasts, macrophages. The MMPs are synthesized as inactive zymogens with a pro-peptide domain that must be removed before the 
enzyme is active. Activation of MMPs can be induced by urokinase type (uPA) and tissue-type (tPA) plasminogen activators that cleave plasminogen into active plasmin. MMP-9, but not other MMPs, is able to upregulate biologically active proteins such as the profibrotic growth factor TGF- $\beta$ (Rutschow et al 2006).

A major control point in the regulation of active enzyme is inhibition of the active form by their tissue family of inhibitors. TIMPs comprise a family of four protease inhibitors (TIMP-1 to TIMP-4), which are expressed in a tissue specific pattern and regulate the function of MMPs either by inhibiting active MMPs or by controlling their activation process. Overall, all MMPs are inhibited by TIMPs once they are activated, with most of the MMPs being inhibited by TIMP-1. The gelatinases (MMP-2 and MMP-9) can form complexes with TIMPs when the enzymes are in the latent form. The complex of latent MMP-2 (pro-MMP-2) with TIMP-2 serves to facilitate the activation of pro-MMP-2 at the cell surface by MT1-MMP (MMP-14), a membrane-anchored MMP. The role of the pro-MMP-9/TIMP-1 complex is unknown.

An imbalance between MMPs and TIMPs plays an important role in ECM modeling that favors tissue fibrosis. For example, the imbalance between the MMP-2 and TIMP-2, caused primarily by an increase in TIMP- 2 activity, may contribute to the pathogenesis of diabetic nephropathy (Han et al 2006). Decreased MMP-2 expression and activity, and up-regulated MMP-9 protein were found in the myocardium of diabetic mice with STZ-induced DCM. These alterations were corrected by ARB treatment (Westermann et al 2007). Myofibroblasts and vascular endothelial cells in PDR membranes expressed an increase in MMP-9 protein and activity (Abu El-Asrar et al 2007). ProMMP-9 and activated MMP-9 levels were also significantly increased in vitreous samples in PDR patients. In addition, TIMP-1 levels were significantly increased in PDR patients. Activated MMP-9 levels in vitreous samples of PDR patients with hemorrhage were higher than those in PDR patients without hemorrhage, suggesting that activated MMP-9 might be involved in hemorrhagic transformation in these patients (Descamps et al 2006).

\section{The plasminogen system}

Plasminogen activator (PA)/plasmin/PA inhibitor (PAI) system is involved in ECM degradation. PAI-1 may promote ECM build-up by preventing plasmin and MMPs activation (McLennan et al 2000). PAI-1 can regulate TGF-beta expression by binding to UPAR and activating the extracellularregulated signal kinase (ERK)/MAPK pathway (Yang et al 2007). PAI-1 plays a critical role in ECM remodeling in the kidney. Normal human kidneys do not express PAI-1 but PAI-1 is overexpressed in pathologic conditions associated with renal fibrosis including diabetic nephropathy (Paueksakon et al 2002; Hagiwara et al 2003). Reactive oxygen species mediate PAI-1 up-regulation in renal cells cultured under high glucose, hypoxia, and with TGF-beta1 (Lee and Ha 2005). PAI-1 induced ECM deposition in diabetic kidney through increased ECM synthesis by TGF-beta 1 up-regulation as well as through decreased ECM degradation by suppression of plasmin and MMP-2 activity (Lee and Ha 2005). Impaired fibrinolysis resulting from high plasma PAI1 can lead to excessive fibrin accumulation within vessels, resulting in atherothrombosis. Increased expression of PAI-1 was found in the arterial wall in patients with type 2 diabetes (Pandolfi et al 2001). This increased vascular expression of PAI-1 promotes neointima formation via accumulation of fibrin or fibrinogen as a result of inhibited clearance of platelet-fibrin thrombi. PAI-1, an acute phase protein, also has been involved in vascular inflammation (Alessi et al 2004).

Figure 4 shows methods in diabetes by which pro-fibrotic growth factors may link with the protease and anti-protease systems to dysregulate ECM turnover and thus cause ECM accumulation.

\section{Endothelin-I}

Endothelin-1 (ET-1) is a potent vasoconstrictor peptide, which can also exert pro-inflammatory, mitogenic and profibrotic effects. Up-regulated by glucose, angiotensin II, TGF- $\beta$, ROS and PDGF in various renal cells (Zoja et al 1991; Kohno et al 1992; Kohno et al 1993; Hughes et al 1996; Hua et al 2001), retinal cells (Chakravarthy et al 1997; Park et al 2000; Yokota et al 2003) and cardiomyocytes, ET-1 has been linked with matrix accumulation in diabetic kidney (Ruiz-Ortega et al 1994; Hargrove et al 2000) and cardiomyocyte hypertrophy (Chen et al 2007), and with hemodynamic and histopathological abnormalities in diabetic retina (Bursell et al 1995; Takagi et al 1996; Chakrabarti et al 1998). Neutralizing ET-antibodies and anti-sense oligonucleotides, as well as ET-receptor antagonist treatment reduced proteinuria and the production of ECM proteins in the kidney (Li et al 1999; Hocher et al 2001; Sugimoto et al 2002) and prevented myocardial and coronary dysfunction (Ding et al 2006; Wolkart et al 2006) in experimental diabetes.

\section{Markers of fibrosis in biological fluids in diabetes}

In order to assess accurately the morphological changes in the target organs and the extent to which the fibrotic changes 


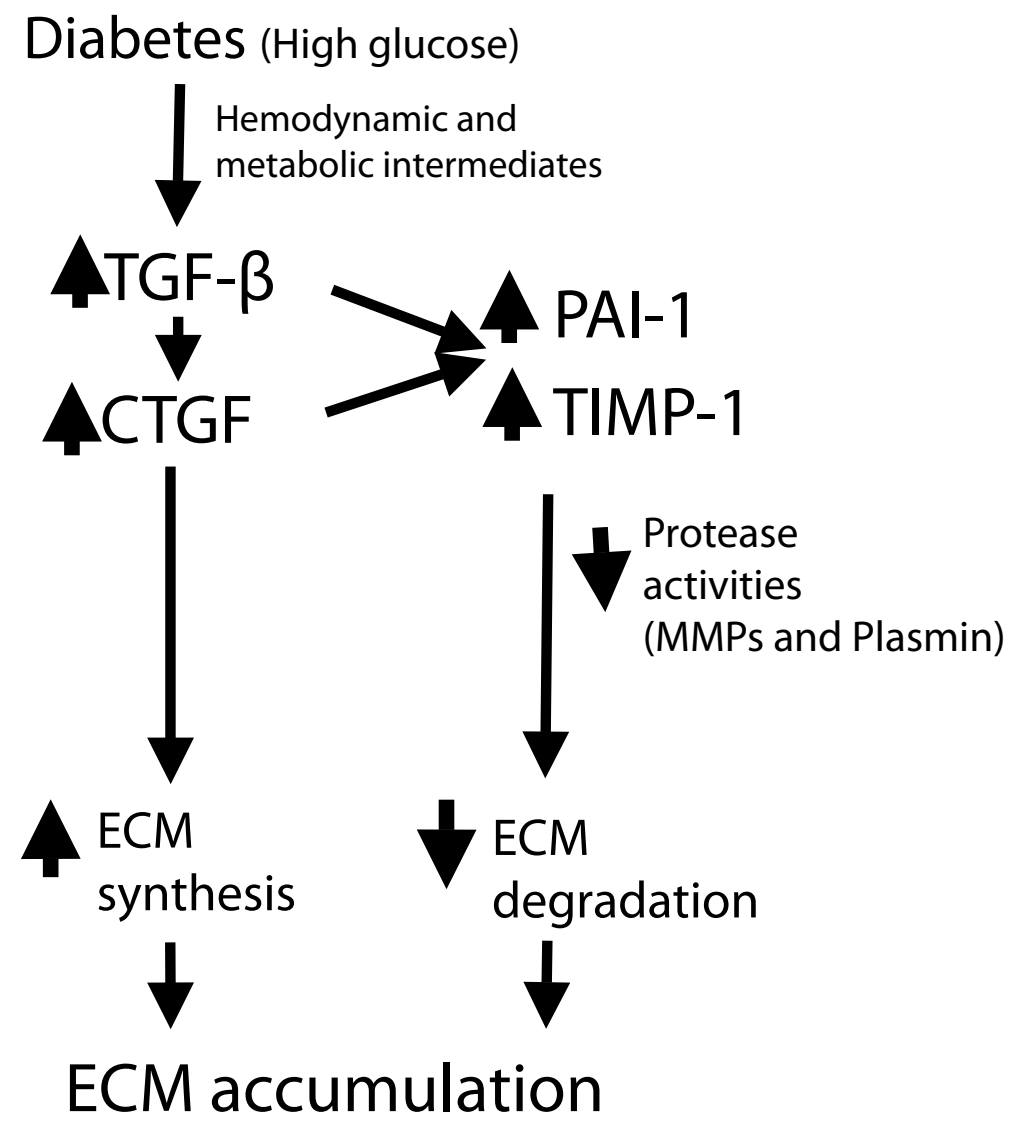

Figure 4 One pathogenic pathway by which high glucose in diabetes and hypertension work through prosclerotic growth factors to dysregulate ECM turnover. Both TGF- $\beta$ and CTGF have been shown to induce TIMP-I and PAI-I, resulting in reduced MMP and plasmin activity. This paradigm best applies to diabetic renal disease.

affect their function, invasive studies (tissue biopsy) is commonly required. However, biopsy is not always feasible in human tissues and is associated with obvious risks. Therefore it is highly desirable to potentially estimate the severity of organ fibrosis by measuring ECM factors in biological fluids (peripheral blood or urine). Such markers, if proven they mirror the changes in specific organs structure and function, will allow a better monitoring of the disease. Moreover, if these markers levels show changes with treatment, they will be a useful tool to evaluate the therapeutic interventions. Thus the potential clinical value of the circulating or urinary levels of several ECM components and its regulators have been tested in diabetes and its complications.

\section{ECM formation and degradation markers}

Serum aminoterminal propeptide of type III (PIIINP) or type I (PINP) procollagen and carboxyterminal propeptide of type I procollagen (PICP) are released in a stoichiometric manner with collagen type III or I molecules during collagen biosynthesis, and therefore they are considered markers of the synthesis and deposition of type III and I collagen (Jensen et al 1990; Risteli et al 1995; Weber 1997). However, there is evidence that some of the PIIINP is also released during collagen degradation, because these propeptides are not completely cleaved during collagen synthesis (Fleischmajer et al 1985). Therefore, PIIINP could reflect both synthesis and degradation of collagen.

Circulating levels of collagen have been suggested as indicators of diabetic complications. Elevated serum levels of both PIIINP and laminin were associated with the development of diabetic microangiopathy (Okazaki et al 1988). Another study (Migdalis et al 1994) found elevated serum PIIINP levels in type 2 diabetic subjects with peripheral vascular disease and proposed that this reflected an increase in collagen deposition in the large arteries that accompanies the development of macroangiopathy. Serum PIIINP was also increased in type 2 diabetic patients with nephropathy (Ishimura et al 1996).

PICP concentration did not differ between uncomplicated type 2 diabetic patients and controls, but it was increased in complicated diabetes and related to the progression of nephropathy (Inukai et al 2000). In contrast, other investigators 
found decreased levels of serum PICP but increased PIIINP concentrations in subjects with proliferative retinopathy compared with those with no retinopathy (Arkkila et al 2001). Similarly, hypertensive type 2 diabetic patients had higher mean levels of PIIINP than controls, and lower mean levels of PINP and PICP (Alla et al 2006). No association between collagen markers and neuropathy was found (Arkkila et al 2001).

\section{ECM regulators as systemic fibrosis markers}

In patients with type 1 diabetes plasma and urinary TGF- $\beta 1$ levels were significantly higher than in controls. The effect of metabolic control on plasma TGF- $\beta$ level is controversial (Azar et al 2000; Flores et al 2004; Thrailkill et al 2007). Increased TGF- $\beta$ levels in both plama and urine were found especially in relation to diabetic nephropathy (Pfeiffer et al 1996; Houlihan et al 2002). Urinary TGF-beta significantly decreased with ACEI, ARB or thiazolinediones treatment, in parallel with a decrease in albuminuria (Matos et al 2005; Katavetin et al 2006; Song et al 2006; Woo et al 2006).

While it seems correlated with glycemic control (Kakizawa et al 2004), plasma VEGF concentration was not strongly correlated with risk factor status or microvascular disease in type 1 diabetes, nor was affected by ACE inhibition (Chaturvedi et al 2001). Urinary VEGF concentrations were significantly higher in the diabetic groups, even at the normoalbuminuric stage, with further increase as diabetic nephropathy advanced (Kim et al 2004).

Diabetes status is associated with dysregulation in the circulating MMP/TIMP system even in the absence of complications. Thus, serum MMP-9 and TIMP-1 levels are increased in both type 1 (Maxwell et al 2001) and type 2 diabetes (Tayebjee et al 2004), with no changes in MMP-2 concentration. In contrast, in another study urine and plasma MMP-2 levels and plasma MMP-2 activity were all significantly elevated in type 1 diabetic patients, with urine MMP-2 correlated with higher $\mathrm{HbA} 1 \mathrm{c}$, longer duration of diabetes, evidence of renal hyperfiltration and the presence of microalbuminuria (Thrailkill et al 2007). Increased serum MMP-2 and TIMP-1 concentrations, but no elevation of MMP-9 levels, were also found in a cohort of diabetic patients with mild or no complications (Lee et al 2005).

Some therapies have been proven efficient in reduction the plasma/serum MMPs and TIMP-1 levels in diabetic patients. Thiazolidinediones, which act via the PPAR $\gamma$ receptor, reduced the increase in circulating levels of MMP-9 but had no effect on circulating MMP-2. Furthermore, reductions in MMP-9 levels were associated with decrease in other inflammatory markers, such as C-reactive protein, PAI-1, IL-6, TNF- $\alpha$ and serum amyloid A (Haffner et al 2002; Marx et al 2003; Hanefeld et al 2007).

Circulating MMP-9 and TIMP-1 could also be reduced by lipid reduction therapy (plasma LDL apheresis) in diabetic patients with end-stage renal disease and arteriosclerosis obliterans (Nakamura et al 2003). Multifactorial cardiovascular risk reduction therapy with intensive glucose control and statin therapy caused significant reductions in circulating TIMP-1 levels (Tayebjee et al 2004). This effect was probably independent of blood pressure lowering, as the latter was relatively well controlled from the outset and did not fall significantly.

\section{Current evidence for clinical utility of markers of fibrosis in diabetes Diabetic renal disease}

Type IV collagen in the circulation or urine has been identified as a possible indicator of renal injuries, especially in early stages of diabetic nephropathy, in numerous, albeit relatively small studies (Watanabe et al 1991; Kotajima et al 2000; Xu et al 2002; Tashiro et al 2004). Both serum and urinary type IV collagen increased in accordance with the clinical stage of the renal disease (Watanabe et al 1991, 2000; $\mathrm{Xu}$ et al 2002; Tashiro et al 2004). Serum carboxy-terminal propeptide type I procollagen (P1CP) levels may also reflect the progression of diabetic nephropathy in patients with type 2 diabetes (Inukai et al 2000). In type 1 diabetes, measurement of syndecan-1 in serum has shown significant increase even at the microalbuminuric stage compared to normoalbuminuric patients (Svennevig et al 2006). TGF- $\beta$ levels in serum were increased in patients with diabetic nephropathy (Sharma et al 1999) and decreased with ACEI (Ellis et al 1998; Sharma et al 1999).

Urinary levels of collagen IV positively correlated with uPA, and that of fibronectin negatively correlated with PAI-1 in the diabetic patients with microalbuminuria (Woo et al 2006). Urinary TGF- $\beta$ was significantly increased in type 2 diabetic patients with micro- or macroalbuminuria. ACEI, $\mathrm{ARB}$, and TZD significantly reduced urinary excretion of TGF- $\beta$ in these patients (Houlihan et al 2002; Praga et al 2003; Matos et al 2005; Katavetin et al 2006; Song et al 2006; Woo et al 2006).

Increasing evidence has emerged on circulating and urinary CTGF as indicators of renal disease in diabetes. Elevated plasma CTGF concentrations have been found in diabetic nephropathy. CTGF levels in the circulation correlated with 
urinary albumin excretion, creatinine clearance, glycemic control and duration of diabetes (Roestenberg et al 2004). Of note, there was a wide overlap in plasma CTGF between normoalbuminuric patients and those with diabetic nephropathy. Urinary concentrations of CTGF (U-CTGF) has been more extensively investigated than circulating CTGF, in diabetic renal disease (Gilbert et al 2003; Riser et al 2003; Nguyen et al 2006). U-CTGF was correlated with clinical markers of renal disease severity (urinary albumin excretion rate and glomerular filtration rate). Furthermore, the association of U-CTGF with diabetic nephropathy was comparable with that of the established risk factors: HbA1c and systemic blood pressure. Significantly higher in patients with microalbuminuria or overt nephropathy, urinary CTGF excretion varied largely across the studies, from 1.6-fold (Nguyen et al 2006) to 6-fold (Riser et al 2003) and were 10-100-fold higher (Gilbert et al 2003) in diabetic nephropathy versus normoalbuminuric subjects. Large overlaps in U-CTGF were also noted between patients and controls (Nguyen et al 2006). In patients with DN, U-CTGF correlated positively with urinary albumin excretion and negatively with GFR (Nguyen et al 2006). It is unclear to what extent plasma CTGF levels contribute to U-CTGF. CTGF and its fragments are predicted to be cleared from plasma by glomerular filtration.

Animal studies have shown increased CTGF mRNA in renal cortex in a very early phase of nephropathy, which paralleled an increase in plasma and U-CTGF (Roestenberg et al 2006). Local production of CTGF in the kidney, renal filtration of (elevated) plasma CTGF, together with tubular dysfunction and/or saturation of tubular reabsorption capacity in proteinuric patients may all be involved in increased U-CTGF (Nguyen et al 2006). Interventional studies have shown that in type 1 diabetes with nephropathy, RAS blockade with ARB significantly decreased U-CTGF concentration, and this reduction was associated with a slower rate of decline in GFR in a cohort of hypertensive type 1 diabetic patients with diabetic kidney disease (Andersen et al 2005). However, plasma CTGF remained unchanged throughout the study, suggesting that circulating CTGF is at least partly independent of U-CTGF and renal dysfunction.

In diabetic patients, plasma VEGF levels were found to be positively correlated with plasma urea and urinary ACR, and urinary VEGF was positively correlated with urinary ACR and creatinine. Urinary VEGF and serum creatinine were independently correlated with urinary ACR (Kim et al 2004). Urinary excretion of VEGF increased during the earlier stage of diabetic nephropathy and was significantly correlated with urinary albumin excretion. This suggests that urinary VEGF might be used as a sensitive marker of diabetic nephropathy and for predicting disease progression (Kim et al 2004). In addition, another study implicated the potential of plasma VEGF as a DN marker (Baba et al 2004).

Dysregulations in circulating and urinary MMP/TIMP systems have been found in diabetic renal disease. Thus, increased levels of plasma MMP-9 have been shown in DN patients (Nakamura et al 2000; Zaoui et al 2000), and were significantly reduced by ACEI treatment (Nakamura et al 2000). Moreover, it seems that elevation in plasma MMP-9 may precede the onset of microalbuminuria in type 2 diabetic patients (Ebihara et al 1998). Higher levels of MMP-9 were also found in the urine of type 2 diabetic patients with macroalbuminuria (Tashiro et al 2004). Interestingly, urinary MMP-9 levels were elevated not only in patients with diabetic renal disease but also in their first-degree relatives when compared with healthy controls (Zaoui et al 2000). It has been suggested that increased urinary MMP-2 and MMP-9 activities, but not serum MMP levels, may be sensitive markers of the extent of renal disease in type 1 diabetic patients (Tashiro et al 2004). Urine MMP-2 concentrations correlated with higher $\mathrm{HbA} 1 \mathrm{c}$ levels, longer duration of disease, evidence of renal hyperfiltration, and the presence of microalbuminuria (Thrailkill et al 2007).

Another study has shown a significant increase in urinary TIMP-1 in association with urinary albumin and the progress of glomerular diffuse lesions, while no correlation between serum TIMP-1 and urinary TIMP-1 was found (Kanauchi et al 1996). TIMP-1 was also increased in the urine in a group of nondiabetic patients with chronic renal disease and was correlated with progressive reduction in renal function, but not with proteinuria (Horstrup et al 2002). In an animal model urinary protein excretion showed a significant positive correlation with glomerular and tubular TIMP-2 protein, and a negative correlation with MMP-2 expression (Han et al 2006).

\section{Diabetic retinopathy}

Increased synthesis of type III collagen (serum PIIINP), reflecting deposition of matrix and $\mathrm{BM}$ connective tissue, has been reported in patients with DPR (Arkkila et al 2001). While some investigators have found no significant differences of serum carboxy-terminal propeptide of human type I procollagen (PICP) across the differing severity of diabetic retinopathy in type 2 diabetic patients (Inukai et al 2000), others have actually observed progressively decreased levels of serum PICP, which can result in weakened vascular integrity in subjects with retinopathy (Arkkila et al 2001). 
Diabetic retinopathy is associated with increased concentrations of type IV collagen in serum (Yano et al 1998; Kotajima et al 2001). Although in the vitreous the NH2terminal CTGF fragment content was increased in patients with active PDR, suggesting that it may play a pathogenic role or may represent a surrogate marker of CTGF activity in DR (Hinton et al 2004), the elevated level of plasma CTGF found in the circulation in patients with DR compared with patients without DR seems likely to be due to associated nephropathy rather than to the retinopathy itself(Roestenberg et al 2004). In addition, no changes in urinary CTGF were noted in DR (Nguyen et al 2006).

Increased plasma levels of VEGF and Ang II were found in diabetic patients, with the highest VEGF and Ang II levels being seen among patients with pre-proliferative and proliferative retinopathy (Lip et al 2004). The clinical utility of plasma VEGF levels after photocoagulation has yielded contradictory results (Lip et al 2000; Lip et al 2004).

Diabetic patients with retinopathy also displayed elevated systemic values of MMP-9 and MMP-9/TIMP-1 ratio when compared with patients without retinopathy. Logistic regression analysis identified diabetes duration firstly, and MMP-9 serum levels secondly as significant and independent variables associated with the existence of retinopathy in type 1 diabetic patients who were free of other overt vascular complications (Jacqueminet et al 2006).

\section{Diabetic cardiomyopathy, heart failure}

A strong correlation has been reported between myocardial collagen content and serum concentration of PICP in systemic hypertension (Querejeta et al 2000). Moreover, serum PICP has been found to be secreted by the heart via the coronary sinus in patients with hypertensive heart disease (Querejeta et al 2004). Thus, even if these markers could be released from various other tissues in diabetes or hypertension, the measurement of serum collagen degradation products may offer a reasonable evaluation of myocardial ECM changes in diabetes. In a highly selected group of uncomplicated type 2 diabetic patients, parameters of myocardial function were positively correlated with glutathione peroxidase and serum PICP, but not with levels of angiotensin II, aldosterone or endothelin-1 (Gonzalez-Vilchez et al 2005). Serum propeptide of procollagen type I (PIP) appears an independent predictor of new heart failure episodes, readmission and death and a single serum measurement of PIP may have prognostic value in patients presenting with decompensated heart failure (Ruiz-Ruiz et al 2007).
In hypertensive subjects, plasma TIMP-1 levels were increased and associated with LVH and LV diastolic impairment in some (Laviades et al 1998; Lindsay et al 2002; Timms et al 2002) but not all studies (Li-Saw-Hee et al 2000). Treatment of hypertension with ACEI has been shown to decrease TIMP-1 levels (Laviades et al 1998). Previous studies of small samples of patients with heart failure or LV dilatation have yielded inconsistent results, with both increased and decreased levels of myocardial or serum TIMP-1 being reported. (Li et al 1998; Schwartzkopff et al 2002). The Framingham Heart Study (Sundstrom et al 2004) has shown that plasma total TIMP-1 is directly related to major CVD risk factors and to echocardiographic indices of $\mathrm{LVH}$, and inversely to systolic dysfunction.

It has also been suggested that elevated TIMP-1 might be a useful noninvasive marker of left ventricular diastolic dysfunction and fibrosis (Lindsay et al 2002). Serum TIMP-1 concentrations over $500 \mathrm{ng} / \mathrm{ml}$ showed good specificity and positive predictive value for detecting diastolic dysfunction among untreated patients with hypertension (Lindsay et al 2002). In an asymptomatic population with either diabetes or hypertension, but with no evidence of $\mathrm{LV}$ hypertrophy, plasma TIMP-1 negatively correlated with e' (early diastolic velocity at the annulus). This suggests that the higher circulating levels of TIMP-1 may reflect structural changes within the heart that result in diastolic dysfunction. The correlation was however stronger among the hypertensive patients when compared with the diabetic group, suggesting again that systemic hypertension may mainly mediate the TIMP-1 and diastolic dysfunction link (Tayebjee et al 2005a).

Increased serum levels of AGEs were associated with heart stiffness in patients with type 1 diabetes, possibly mediated by the cross-linking properties of AGEs (Berg et al 1999).

\section{Atherosclerosis and arteriosclerosis}

Plasma plasminogen activator inhibitor (PAI)-1, a potent inhibitor of fibrinolysis, was elevated in a number of clinical situations that are associated with high incidence of cardiovascular disease (CVD) (obesity, hypertension, type 2 diabetes) (Hoekstra et al 2004).

Serum 7S-collagen levels in diabetic patients with essential hypertension were significantly higher than in normal subjects, and significantly correlated with systolic blood pressure. Thus it has been suggested that the metabolic alteration of basement membrane occurring in patients with diabetes mellitus may worsen in the presence of high systolic 
blood pressure (Yano et al 1997). In hypertensive type 2 diabetic patients there were also noted an imbalance between serum MMP-1 which was decreased, and its tissue inhibitor, TIMP-1 which was not significantly changed compared to controls (Alla et al 2006).

Diabetic patients with acute coronary syndromes showed increased plasma levels of MMP-9, TIMP-1, and TIMP-2 (Derosa et al 2007). A high percent of patients with coronary artery disease (CAD) or acute coronary syndromes (ACS) had elevated urine values of MMP-9 and TIMP-1 suggesting that these variables might be a useful marker of atherosclerotic disease (Fitzsimmons et al 2006). Plasma levels of MMP-9, TIMP-2, but not TIMP-1 were high in patients with stable CAD compared with healthy controls. However, no correlation with severity of CAD or collateralization was found (Tayebjee et al 2005b).

In patients with premature coronary atherosclerosis, the levels of plasma MMP-9 and TIMP-1 were significantly higher, and the levels of MMP-2, MMP-3, and TIMP-2 were significantly lower than those of controls, with significant positive correlation between plasma MMP-9 levels and lowdensity lipoprotein (LDL)-cholesterol levels, and significant negative correlation between plasma MMP-9 levels and high-density lipoprotein (HDL)-cholesterol levels. TIMP-2 levels were negatively correlated with total cholesterol and LDL-cholesterol levels (Noji et al 2001).

In patients with CAD the low TGF- $\beta$ group had a significantly poor prognosis in terms of survival without cardiovascular events and survival without coronary interventions as compared with the high TGF- $\beta$ group, while other prognoses were comparable between the two groups. These results suggest that lower plasma concentrations of TGF- $\beta$ may have an adverse prognostic significance in patients with CAD (Tashiro et al 2002). In another study, plasma TGF- $\beta$ levels were significantly lower in patients with ischemic heart disease than they were in controls (Tashiro et al 1997).

\section{Liver fibrosis}

The serum glyceraldehyde-derived AGEs level may be a useful biomarker for discriminating NASH from simple steatosis. Moreover, it correlated with adiponectin (Hyogo et al 2007). Serum hyaluronic acid could identify NAFLD in patients with severe fibrosis in some (Sakugawa et al 2005; Kaneda et al 2006), but not all studies (Yoneda et al 2007). Type IV collagen $7 \mathrm{~s}$ domain and type IV collagen $7 \mathrm{~s}$ domain concentrations in the circulation have been identified as potential markers in differentiating between NASH and NAFLD (Sakugawa et al 2005), and between advanced and mild liver fibrosis (Yoneda et al 2007). Serum levels of endothelin-1 (ET-1), an inflammatory and marker of increased endothelial tone, also showed a significant positive correlation with liver fibrosis severity in patients with NASH (Degertekin et al 2007).

TIMP-1 and MMP-1 levels in serum or peripheral blood mononuclear cells (PBMCs) seem to have some value in assessing liver fibrosis. The combination of serum PDGF-BB, TIMP-1 mRNA and TIMP-1mRNA/MMP-1mRNA ratio in PBMCs was suggested as an efficient test in screening for the presence of liver fibrosis (Zhang et al 2003).

\section{Research required in circulating and urinary markers of fibrosis in diabetes}

Important issues appear when interpreting levels of the ECM markers and their regulators in blood or urine from diabetic patients. First, it is not yet clear whether the assessment of these markers in biological fluids provide clinically valuable information of the fibrosis process in the affected organs and whether tissue levels are reflected accurately in blood or urine. Factors such as the relative contribution of a tissue to a particular circulating marker and also the rate of clearance of the marker from the circulation and its dependence on renal function can have significant effects on its level. Nevertheless, the fact that different therapies impact upon their levels indicates that they may be involved in the pathological process.

A second issue is the presence of conditions that commonly co-exist with diabetes, such as hypertension and/or dyslipidemia, which could also influence the levels of circulating/urinary markers of fibrosis. The differentiation between the contribution of diabetes and other co-morbidities to the total level of ECM markers in blood/urine could therefore be difficult to assess.

Figure 5 summarizes the main findings of circulating and urinary markers and their regulators and their potential value in diabetes complications. At this time, Type IV collagen and CTGF in plasma and urine hold promise in diabetic renal disease, MMP-9 has promise in acute coronary syndromes as does TIMP-1 and also in myocardial dysfunction. Longitudinal and large studies in appropriate populations of people with diabetes, will be needed to further investigate the possible clinical value of these and other ECM components and ECM regulators as makers for incipient or progressive diabetes complications. Ideally, such markers in their natural history and after therapy, would show predictive value 


\begin{tabular}{|c|c|c|c|c|c|}
\hline & Diabetic Nephropathy & Diabetic Retinopathy & $\begin{array}{l}\text { Diabetic Cardiomyopathy } \\
\text { Diastolic Dysfunction }\end{array}$ & $\begin{array}{c}\text { NASH } \\
\text { Liver Fibrosis }\end{array}$ & $\begin{array}{l}\text { Macrovascular } \\
\text { Disease }\end{array}$ \\
\hline Type I collagen & Increased in serum (Inukai et al 2000) & $\begin{array}{l}\text { Decreased in serum in T1DM } \\
\text { (Arkkila et al 2001) }\end{array}$ & & & \\
\hline $\begin{array}{l}\text { Type III } \\
\text { collagen }\end{array}$ & $\begin{array}{l}\text { Increased in serum } \\
\text { (Ishimura et al 1996) }\end{array}$ & $\begin{array}{l}\text { Increased in serum in PRD in } \\
\text { T1DM (Arkkila et al 2001) }\end{array}$ & & & \\
\hline $\begin{array}{l}\text { Type IV } \\
\text { collagen }\end{array}$ & $\begin{array}{l}\text { Increased in serum (Watanabe T. et al } \\
\text { 1991; Xu et al 2002) and urine } \\
\text { (Watanabe T. et al 1991; Kotajima et al } \\
\text { 2000; Watanabe H. et al 2000; Cohen } \\
\text { et al 2001; Tashiro et al 2004) }\end{array}$ & $\begin{array}{l}\text { Increased in serum (Yano et al } \\
\text { 1998; Kotajima et al 2001), } \\
\text { in vitreous (Kotajima et al } \\
\text { 2001) }\end{array}$ & & $\begin{array}{l}\text { Increased in serum } \\
\text { (Yoneda et al 2007) }\end{array}$ & \\
\hline $\begin{array}{l}\text { Other ECM } \\
\text { proteins }\end{array}$ & $\begin{array}{l}\text { Syndecan-1 increased in serum in } \\
\text { T1DM (Svennevig et al 2006) } \\
\text { Fibronectin increased in urine } \\
\text { (Takahashi 1995) }\end{array}$ & & & $\begin{array}{c}\text { Type VI collagen } \\
\text { increased in serum } \\
\text { (Sakugawa et al 2005) }\end{array}$ & $\begin{array}{l}\text { Plasma hyaluronan } \\
\text { increased in T1DM } \\
\text { (Nieuwdorp et al 2007) }\end{array}$ \\
\hline TGF- $\beta$ & Increased in urine (Sharma et al 1997) & & & & \\
\hline CTGF & $\begin{array}{l}\text { Increased in plasma in T1DM } \\
\text { (Roestenberg et al 2004) and urine } \\
\text { (Riser et al 2003) in T1DM (Gilbert et al } \\
\text { 2003; Nguyen et al 2006) }\end{array}$ & $\begin{array}{l}\text { No change (Roestenberg et al } \\
\text { 2004) }\end{array}$ & & & \\
\hline $\begin{array}{l}\text { Other growth } \\
\text { factors }\end{array}$ & $\begin{array}{l}\text { VEGF increased in urine (Kim et al } \\
\qquad 2004 \text { ) }\end{array}$ & $\begin{array}{l}\text { VEGF increased in plasma } \\
\text { (Lip et al 2000; Lip et al 2004) }\end{array}$ & & $\begin{array}{l}\text { PDGF-BB increased in } \\
\text { serum (Zhang et al } \\
\text { 2003) }\end{array}$ & \\
\hline TIMP-1 & & & $\begin{array}{l}\text { Increased in plasma LV diastolic } \\
\text { dysfunction and fibrosis in } \\
\text { hypertenstion (Lindsay et al } \\
\text { 2002) and T2DM (Tayebjee et al } \\
\text { 2005) }\end{array}$ & & $\begin{array}{l}\text { Plasma TIMP-1 and TIMP-2 } \\
\text { increased in diabetic } \\
\text { patients with acute } \\
\text { coronary syndromes } \\
\text { (Derosa et al 2007) }\end{array}$ \\
\hline MMPs & $\begin{array}{l}\text { MMP-9 increased in plasma (Ebihara } \\
\text { et al 1998; Nakamura et al 2000) and } \\
\text { urine (Tashiro et al 2004) } \\
\text { MMP-2 increased in urine in T1DM } \\
\text { (Thrailkill et al 2007) }\end{array}$ & $\begin{array}{l}\text { MMP-9 increased in serum in } \\
\text { T1DM (Jacqueminet et al } \\
\text { 2006) }\end{array}$ & & & $\begin{array}{l}\text { Plasma MMP-9 increased } \\
\text { in diabetic patients with } \\
\text { acute coronary syndromes } \\
\text { (Derosa et al 2007) }\end{array}$ \\
\hline PAI-1 & & & & & $\begin{array}{l}\text { Increased in plasma } \\
\text { (Vaughan 2005) }\end{array}$ \\
\hline
\end{tabular}

Figure 5 Summary of the main circulating factors, both ECM proteins and their regulators (growth factors and protease/anti-protease systems) that have been reported to be increased in subjects with diabetic tissue complications that are characterized by fibrosis.

independent of other common clinical variables such as hypertension, degree of glycemic control, and microalbuminuria. It is envisaged that clinically verified algorithms will be generated where automated plasma or urine measures will aid in the calculation of risk of tissue fibrosis, and related organ dysfunction. It may be that other, tissue specific measures such as BNP for the heart or liver function tests for liver fibrosis, will be useful in combination with such ECM markers. Urinary measures do appear to often be independent of circulating levels, although whether such measures have advantage over albuminuria and estimated GFR levels, remains to be determined.

\section{References}

Abdel-Wahab N, Weston BS, Roberts T, et al. 2002. Connective tissue growth factor and regulation of the mesangial cell cycle: role in cellular hypertrophy. J Am Soc Nephrol, 13:2437-45.

Abreu JG, Ketpura NI, Reversade B, et al. 2002. Connective-tissue growth factor (CTGF) modulates cell signalling by BMP and TGF-beta. Nat Cell Biol, 4:599-604.

Abu El-Asrar AM, Van den Steen PE, Al-Amro SA, et al. 2007. Expression of angiogenic and fibrogenic factors in proliferative vitreoretinal disorders. Int Ophthalmol, 27:11-22. 
Adler SG, Kang SW, Feld S, et al. 2001. Glomerular mRNAs in human type 1 diabetes: biochemical evidence for microalbuminuria as a manifestation of diabetic nephropathy. Kidney Int, 60:2330-6.

Alessi MC and Juhan-Vague I. 2004. Contribution of PAI-1 in cardiovascular pathology. Arch Mal Coeur Vaiss, 97:673-8.

Alla F, Kearney-Schwartz A, Radauceanu A, et al. 2006. Early changes in serum markers of cardiac extra-cellular matrix turnover in patients with uncomplicated hypertension and type II diabetes. Eur J Heart Fail, 8:147-53.

Andersen S, van Nieuwenhoven FA, Tarnow L, et al. 2005. Reduction of urinary connective tissue growth factor by Losartan in type 1 patients with diabetic nephropathy. Kidney Int, 67:2325-9.

Angulo P. 2002. Nonalcoholic fatty liver disease. $N$ Engl J Med, 346:1221-31.

Arkkila PE, Ronnemaa T, Koskinen PJ, et al. 2001. Biochemical markers of type III and I collagen: association with retinopathy and neuropathy in type 1 diabetic subjects. Diabet Med, 18:816-21.

Azar ST, Salti I, Zantout MS, et al. 2000. Alterations in plasma transforming growth factor beta in normoalbuminuric type 1 and type 2 diabetic patients. J Clin Endocrinol Metab, 85:4680-2.

Baba T, Osterby R, Neugebauer-Baba S, et al. 2004. No nephropathy in Type 2 diabetic patient with POEMS syndrome with an elevated plasma VEGF. Diabet Med, 21:292-4.

Baelde HJ, Eikmans M, Lappin DW, et al. 2007. Reduction of VEGF-A and CTGF expression in diabetic nephropathy is associated with podocyte loss. Kidney Int, 71:637-45.

Bataller R, Sancho-Bru P, Gines P, et al. 2003. Activated human hepatic stellate cells express the renin-angiotensin system and synthesize angiotensin II. Gastroenterology, 125:117-25.

Berg TJ, Snorgaard O, Faber J, et al. 1999. Serum levels of advanced glycation end products are associated with left ventricular diastolic function in patients with type 1 diabetes. Diabetes Care, 22:1186-90.

Bishop JE and Laurent GJ. 1995. Collagen turnover and its regulation in the normal and hypertrophying heart. Eur Heart J, 16(Suppl C):38-44.

Blom IE, van Dijk AJ, Wieten L, et al. 2001. In vitro evidence for differential involvement of CTGF, TGFbeta, and PDGF-BB in mesangial response to injury. Nephrol Dial Transplant, 16:1139-48.

Border WA and Noble NA. 1998. Interactions of transforming growth factorbeta and angiotensin II in renal fibrosis. Hypertension, 31:181-8.

Brigstock DR. 2002. Regulation of angiogenesis and endothelial cell function by connective tissue growth factor (CTGF) and cysteine-rich 61 (CYR61). Angiogenesis, 5:153-65.

Brilla CG, Scheer C and Rupp H. 1997. Renin-angiotensin system and myocardial collagen matrix: modulation of cardiac fibroblast function by angiotensin II type 1 receptor antagonism. J Hypertens Suppl, 15: S13-9.

Brownlee M. 2001. Biochemistry and molecular cell biology of diabetic complications. Nature, 414:813-20.

Brownlee M and Spiro RG. 1979. Biochemistry of the basement membrane in diabetes mellitus. Adv Exp Med Biol, 124:141-56.

Brownlee M, Cerami A and Vlassara H. 1988. Advanced glycosylation end products in tissue and the biochemical basis of diabetic complications. N Engl J Med, 318:1315-21.

Bugianesi E, Leone N, Vanni E, et al. 2002. Expanding the natural history of nonalcoholic steatohepatitis: from cryptogenic cirrhosis to hepatocellular carcinoma. Gastroenterology, 123:134-40.

Bursell SE, Clermont AC, Oren B, et al. 1995. The in vivo effect of endothelins on retinal circulation in nondiabetic and diabetic rats. Invest Ophthalmol Vis Sci, 36:596-607.

Candido R, Forbes JM, Thomas MC, et al. 2003. A breaker of advanced glycation end products attenuates diabetes-induced myocardial structural changes. Circ Res, 92:785-92.

Cha DR, Kang YS, Han SY, et al. 2005. Role of aldosterone in diabetic nephropathy. Nephrology (Carlton), 10(Suppl):S37-9.

Chakrabarti S, Gan XT, Merry A, et al. 1998. Augmented retinal endothelin1, endothelin-3, endothelin A and endothelin B gene expression in chronic diabetes. Curr Eye Res, 17:301-7.
Chakravarthy U, Hayes RG, Stitt AW, et al. 1997. Endothelin expression in ocular tissues of diabetic and insulin-treated rats. Invest Ophthalmol Vis Sci, 38:2144-51.

Chaqour B, Yang R and Sha Q. 2006. Mechanical Stretch Modulates the Promoter Activity of the Profibrotic Factor CCN2 through Increased Actin Polymerization and NF-\{kappa\}B Activation. J Biol Chem, 281:20608-22.

Charlton M. 2004. Nonalcoholic fatty liver disease: a review of current understanding and future impact. Clin Gastroenterol Hepatol, 2:1048-58.

Chaturvedi N, Fuller JH, Pokras F, et al. 2001. Circulating plasma vascular endothelial growth factor and microvascular complications of type 1 diabetes mellitus: the influence of ACE inhibition. Diabet Med, 18:288-94.

Chaturvedi N, Sjolie AK, Stephenson JM, et al. 1998. Effect of lisinopril on progression of retinopathy in normotensive people with type 1 diabetes. The EUCLID Study Group. EURODIAB Controlled Trial of Lisinopril in Insulin-Dependent Diabetes Mellitus. Lancet, 351:28-31.

Chen S, Khan ZA, Karmazyn M, et al. 2007. Role of endothelin-1, sodium hydrogen exchanger-1 and mitogen activated protein kinase (MAPK) activation in glucose-induced cardiomyocyte hypertrophy. Diabetes Metab Res Rev, 23:356-67.

Cicha I, Yilmaz A, Klein M, et al. 2005. Connective tissue growth factor is overexpressed in complicated atherosclerotic plaques and induces mononuclear cell chemotaxis in vitro. Arterioscler Thromb Vasc Biol, 25:1008-13.

Cohen MP, Shearman CW and Lautenslager GT. 2001. Serum type IV collagen in diabetic patients at risk for nephropathy. Diabetes Care, 24:1324-7.

Cooker LA, Peterson D, Rambow J, et al. 2007. TNF-\{alpha\}, but not IFN\{gamma\}, regulates CCN2 (CTGF), collagen type I, and proliferation in mesangial cells: possible roles in the progression of renal fibrosis. Am J Physiol Renal Physiol, 293:F157-65.

Crean JK, Finlay D, Murphy M, et al. 2002. The role of p42/44 MAPK and protein kinase $\mathrm{B}$ in connective tissue growth factor induced extracellular matrix protein production, cell migration, and actin cytoskeletal rearrangement in human mesangial cells. J Biol Chem, 277:44187-94.

D'Armiento J. 2002. Matrix metalloproteinase disruption of the extracellular matrix and cardiac dysfunction. Trends Cardiovasc Med, 12:97-101.

Das AK, Das JP and Chandrasekar S. 1987. Specific heart muscle disease in diabetes mellitus - a functional structural correlation. Int J Cardiol, 17:299-302.

de Vriese AS, Tilton RG, Elger M, et al. 2001. Antibodies against vascular endothelial growth factor improve early renal dysfunction in experimental diabetes. J Am Soc Nephrol, 12:993-1000.

Death AK, Fisher EJ, McGrath KC, et al. 2003. High glucose alters matrix metalloproteinase expression in two key vascular cells: potential impact on atherosclerosis in diabetes. Atherosclerosis, 168:263-9.

Degertekin B, Ozenirler S, Elbeg S, et al. 2007. The Serum Endothelin-1 Level in Steatosis and NASH, and Its Relation with Severity of Liver Fibrosis. Dig Dis Sci, April 11.

Derosa G, Cicero AF, Scalise F, et al. 2007. Metalloproteinase-2 and -9 in diabetic and nondiabetic subjects during acute coronary syndromes. Endothelium, 14:45-51.

Derubertis FR and Craven PA. 1994. Activation of protein kinase C in glomerular cells in diabetes. Mechanisms and potential links to the pathogenesis of diabetic glomerulopathy. Diabetes, 43:1-8.

Descamps FJ, Martens E, Kangave D, et al. 2006. The activated form of gelatinase $\mathrm{B} /$ matrix metalloproteinase-9 is associated with diabetic vitreous hemorrhage. Exp Eye Res, 83:401-7.

Di Paolo S, Gesualdo L, Ranieri E, et al. 1996. High glucose concentration induces the overexpression of transforming growth factor-beta through the activation of a platelet-derived growth factor loop in human mesangial cells. Am J Pathol, 149:2095-106.

Ding Y, Zou R, Judd RL, et al. 2006. Endothelin-1 receptor blockade prevented the electrophysiological dysfunction in cardiac myocytes of streptozotocin-induced diabetic rats. Endocrine, 30:121-7. 
Dresow B and Delbruck A. 1984. The isolation and activity of growthstimulating factors from human platelets. J Clin Chem Clin Biochem, 22:527-33.

Duncan MR, Frazier KS, Abramson S, et al. 1999. Connective tissue growth factor mediates transforming growth factor beta-induced collagen synthesis: down-regulation by cAMP. Faseb $J, 13: 1774-86$.

Ebihara I, Nakamura T, Shimada N, et al. 1998. Increased plasma metalloproteinase- 9 concentrations precede development of microalbuminuria in noninsulin-dependent diabetes mellitus. Am J Kidney Dis, 32:544-50.

Edwards IJ, Wagner JD, Vogl-Willis CA, et al. 2004. Arterial heparan sulfate is negatively associated with hyperglycemia and atherosclerosis in diabetic monkeys. Cardiovasc Diabetol, 3:6.

Efrati S, Berman S, Goldfinger N, et al. 2007. Enhanced angiotensin II production by renal mesangium is responsible for apoptosis/proliferation of endothelial and epithelial cells in a model of malignant hypertension. J Hypertens, 25:1041-52.

Ellis D, Forrest KY, Erbey J, et al. 1998. Urinary measurement of transforming growth factor-beta and type IV collagen as new markers of renal injury: application in diabetic nephropathy. Clin Chem, 44:950-6.

Engeli S, Gorzelniak K, Kreutz R, et al. 1999. Co-expression of reninangiotensin system genes in human adipose tissue. J Hypertens, 17:555-60.

Factor SM, Okun EM and Minase T. 1980. Capillary microaneurysms in the human diabetic heart. $N$ Engl J Med, 302:384-8.

Farquhar A, MacDonald MK and Ireland JT. 1972. The role of fibrin deposition in diabetic glomerulosclerosis: a light, electron and immunofluorescence microscopy study. J Clin Pathol, 25:657-67.

Finckenberg P, Inkinen K, Ahonen J, et al. 2003. Angiotensin II induces connective tissue growth factor gene expression via calcineurin-dependent pathways. Am J Pathol, 163:355-66.

Fioretto P and Mauer M. 2007. Histopathology of diabetic nephropathy. Semin Nephrol, 27:195-207.

Fisher EJ, McLennan SV, Yue DK, et al. 1997. High glucose reduces generation of plasmin activity by mesangial cells. Microvasc Res, 53:173-8.

Fitzsimmons PJ, Forough R, Lawrence ME, et al. 2006. Urinary levels of matrix metalloproteinase 9 and 2 and tissue inhibitor of matrix metalloproteinase in patients with coronary artery disease. Atherosclerosis, Aug 28.

Fleischmajer R, Perlish JS and Timpl R. 1985. Collagen fibrillogenesis in human skin. Ann N Y Acad Sci, 460:246-57.

Flores L, Naf S, Hernaez R, et al. 2004. Transforming growth factor beta at clinical onset of Type 1 diabetes mellitus. A pilot study. Diabet Med, 21:818-22.

Forbes JM, Cooper ME, Thallas V, et al. 2002. Reduction of the accumulation of advanced glycation end products by ACE inhibition in experimental diabetic nephropathy. Diabetes, 51:3274-82.

Frazier K, Williams S, Kothapalli D, et al. 1996. Stimulation of fibroblast cell growth, matrix production, and granulation tissue formation by connective tissue growth factor. J Invest Dermatol, 107:404-11.

Fukuda G, Khan ZA, Barbin YP, et al. 2005. Endothelin-mediated remodeling in aortas of diabetic rats. Diabetes Metab Res Rev, 21:367-75.

Fukui M, Nakamura T, Ebihara I, et al. 1992. ECM gene expression and its modulation by insulin in diabetic rats. Diabetes, 41:1520-7.

Geiger M and Binder BR. 1988. Plasminogen activation in diabetes mellitus. Kinetics of plasmin formation with tissue plasminogen activator and plasminogen from individual diabetic donors and with in vitro glucosylated plasminogen. Enzyme, 40:149-57.

Genda A, Mizuno S, Nunoda S, et al. 1986. Clinical studies on diabetic myocardial disease using exercise testing with myocardial scintigraphy and endomyocardial biopsy. Clin Cardiol, 9:375-82.

George J and Tsutsumi M. 2007. siRNA-mediated knockdown of connective tissue growth factor prevents $\mathrm{N}$-nitrosodimethylamine-induced hepatic fibrosis in rats. Gene Ther, 14:790-803.

Gilbert RE, Akdeniz A, Weitz S, et al. 2003. Urinary connective tissue growth factor excretion in patients with type 1 diabetes and nephropathy. Diabetes Care, 26:2632-6.
Gilbert RE, Cox A, Wu LL, et al. 1998. Expression of transforming growth factor-beta1 and type IV collagen in the renal tubulointerstitium in experimental diabetes: effects of ACE inhibition. Diabetes, 47:414-22.

Glick AD, Jacobson HR and Haralson MA. 1992. Mesangial deposition of type I collagen in human glomerulosclerosis. Hum Pathol, 23:1373-9.

Goldin A, Beckman JA, Schmidt AM, et al. 2006. Advanced glycation end products: sparking the development of diabetic vascular injury. Circulation, 114:597-605.

Gomez DE, Alonso DF, Yoshiji H, et al. 1997. Tissue inhibitors of metalloproteinases: structure, regulation and biological functions. Eur J Cell Biol, 74:111-22.

Gomez-Garre D, Ruiz-Ortega M, Ortego M, et al. 1996. Effects and interactions of endothelin-1 and angiotensin II on matrix protein expression and synthesis and mesangial cell growth. Hypertension, 27:885-92.

Gonzalez-Vilchez F, Ayuela J, Ares M, et al. 2005. Oxidative stress and fibrosis in incipient myocardial dysfunction in type 2 diabetic patients. Int $J$ Cardiol, 101:53-8.

Gore-Hyer E, Shegogue D, Markiewicz M, et al. 2002. TGF-beta and CTGF have overlapping and distinct fibrogenic effects on human renal cells. Am J Physiol Renal Physiol, 283:F707-16.

Greene DA, Lattimer SA and Sima AA. 1987. Sorbitol, phosphoinositides, and sodium-potassium-ATPase in the pathogenesis of diabetic complications. N Engl J Med, 316:599-606.

Gressner OA, Lahme B, Demirci I, et al. 2007. Differential effects of TGFbeta on connective tissue growth factor (CTGF/CCN2) expression in hepatic stellate cells and hepatocytes. J Hepatol, Jun 26.

Grotendorst GR, Okochi H and Hayashi N. 1996. A novel transforming growth factor beta response element controls the expression of the connective tissue growth factor gene. Cell Growth Differ, 7:469-80.

Guha M, Xu ZG, Tung D, et al. 2007. Specific down-regulation of connective tissue growth factor attenuates progression of nephropathy in mouse models of type 1 and type 2 diabetes. FASEB J, 21:3355-68.

Haffner SM, Greenberg AS, Weston WM, et al. 2002. Effect of rosiglitazone treatment on nontraditional markers of cardiovascular disease in patients with type 2 diabetes mellitus. Circulation, 106:679-84.

Hagiwara H, Kaizu K, Uriu K, et al. 2003. Expression of type-1 plasminogen activator inhibitor in the kidney of diabetic rat models. Thromb Res, 111:301-9.

Han SY, Jee YH, Han KH, et al. 2006. An imbalance between matrix metalloproteinase-2 and tissue inhibitor of matrix metalloproteinase-2 contributes to the development of early diabetic nephropathy. Nephrol Dial Transplant, 21:2406-16.

Hanefeld M, Marx N, Pfutzner A, et al. 2007. Anti-inflammatory effects of pioglitazone and/or simvastatin in high cardiovascular risk patients with elevated high sensitivity C-reactive protein: the PIOSTAT Study. $J$ Am Coll Cardiol, 49:290-7.

Hanneken A, de Juan E, Jr., Lutty GA, et al. 1991. Altered distribution of basic fibroblast growth factor in diabetic retinopathy. Arch Ophthalmol, 109:1005-11.

Hargrove GM, Dufresne J, Whiteside C, et al. 2000. Diabetes mellitus increases endothelin-1 gene transcription in rat kidney. Kidney Int, $58: 1534-45$.

Hashimoto G, Inoki I, Fujii Y, et al. 2002. Matrix metalloproteinases cleave connective tissue growth factor and reactivate angiogenic activity of vascular endothelial growth factor 165. J Biol Chem, 277:36288-95.

Hayden MR, Sowers JR and Tyagi SC. 2005. The central role of vascular extracellular matrix and basement membrane remodeling in metabolic syndrome and type 2 diabetes: the matrix preloaded. Cardiovasc Diabetol, 4:9.

Heart Outcomes Prevention Evaluation Study Investigators. 2000. Effects of ramipril on cardiovascular and microvascular outcomes in people with diabetes mellitus: results of the HOPE study and MICRO-HOPE substudy. Lancet, 355:253-9.

Hinton DR, Spee C, He S, et al. 2004. Accumulation of NH2-terminal fragment of connective tissue growth factor in the vitreous of patients with proliferative diabetic retinopathy. Diabetes Care, 27:758-64. 
Hishikawa K, Oemar BS, Tanner FC, et al. 1999. Overexpression of connective tissue growth factor gene induces apoptosis in human aortic smooth muscle cells. Circulation, 100:2108-12.

Hocher B, Schwarz A, Reinbacher D, et al. 2001. Effects of endothelin receptor antagonists on the progression of diabetic nephropathy. Nephron, 87:161-9.

Hoekstra T, Geleijnse JM, Schouten EG, et al. 2004. Plasminogen activator inhibitor-type 1: its plasma determinants and relation with cardiovascular risk. Thromb Haemost, 91:861-72.

Horstrup JH, Gehrmann M, Schneider B, et al. 2002. Elevation of serum and urine levels of TIMP-1 and tenascin in patients with renal disease. Nephrol Dial Transplant, 17:1005-13.

Hosoda Y, Okada M, Matsumura M, et al. 1993. Epiretinal membrane of proliferative diabetic retinopathy: an immunohistochemical study. Ophthalmic Res, 25:289-94.

Houlihan CA, Akdeniz A, Tsalamandris C, et al. 2002. Urinary transforming growth factor-beta excretion in patients with hypertension, type 2 diabetes, and elevated albumin excretion rate: effects of angiotensin receptor blockade and sodium restriction. Diabetes Care, 25:1072-7.

Hua H, Goldberg HJ, Fantus IG, et al. 2001. High glucose-enhanced mesangial cell extracellular signal-regulated protein kinase activation and alpha1(IV) collagen expression in response to endothelin-1: role of specific protein kinase C isozymes. Diabetes, 50:2376-83.

Hueber A, Wiedemann P, Esser P, et al. 1996. Basic fibroblast growth factor mRNA, bFGF peptide and FGF receptor in epiretinal membranes of intraocular proliferative disorders (PVR and PDR). Int Ophthalmol, 20:345-50.

Hughes JM, Kuiper EJ, Klaassen I, et al. 2007. Advanced glycation end products cause increased $\mathrm{CCN}$ family and extracellular matrix gene expression in the diabetic rodent retina. Diabetologia, 50:1089-98.

Hughes AK, Stricklett PK, Padilla E, et al. 1996. Effect of reactive oxygen species on endothelin-1 production by human mesangial cells. Kidney Int, 49:181-9.

Hunt JV, Smith CC and Wolff SP. 1990. Autoxidative glycosylation and possible involvement of peroxides and free radicals in LDL modification by glucose. Diabetes, 39:1420-4.

Hyogo H, Yamagishi S, Iwamoto K, et al. 2007. Elevated levels of serum advanced glycation end products in patients with non-alcoholic steatohepatitis. J Gastroenterol Hepatol, 22:1112-9.

Igarashi A, Okochi H, Bradham DM, et al. 1993. Regulation of connective tissue growth factor gene expression in human skin fibroblasts and during wound repair. Mol Biol Cell, 4:637-45.

Ikeda S, Makino H, Haramoto T, et al. 1991. Changes in glomerular extracellular matrices components in diabetic nephropathy. $J$ Diabet Complications, 5:186-8.

Inukai T, Fujiwara Y, Tayama K, et al. 2000. Serum levels of carboxyterminal propeptide of human type I procollagen are an indicator for the progression of diabetic nephropathy in patients with type 2 diabetes mellitus. Diabetes Res Clin Pract, 48:23-8.

Ioachim E, Stefaniotou M, Gorezis S, et al. 2005. Immunohistochemical study of extracellular matrix components in epiretinal membranes of vitreoproliferative retinopathy and proliferative diabetic retinopathy. Eur J Ophthalmol, 15:384-91.

Ishimura E, Nishizawa Y, Shoji S, et al. 1996. Serum type III, IV collagens and TIMP in patients with type II diabetes mellitus. Life Sci, 58:1331-7.

Jacqueminet S, Ben Abdesselam O, Chapman MJ, et al. 2006. Elevated circulating levels of matrix metalloproteinase- 9 in type 1 diabetic patients with and without retinopathy. Clin Chim Acta, 367:103-7.

Jensen LT, Horslev-Petersen K, Toft P, et al. 1990. Serum aminoterminal type III procollagen peptide reflects repair after acute myocardial infarction. Circulation, 81:52-7.

Jerdan JA and Glaser BM. 1986. Retinal microvessel extracellular matrix: an immunofluorescent study. Invest Ophthalmol Vis Sci, 27:194-203.

Kagami S, Border WA, Miller DE, et al. 1994. Angiotensin II stimulates extracellular matrix protein synthesis through induction of transforming growth factor-beta expression in rat glomerular mesangial cells J Clin Invest, 93:2431-7.
Kakizawa H, Itoh M, Itoh Y, et al. 2004. The relationship between glycemic control and plasma vascular endothelial growth factor and endothelin-1 concentration in diabetic patients. Metabolism, 53:550-5.

Kanauchi M, Nishioka H, Nakashima Y, et al. 1996. Role of tissue inhibitors of metalloproteinase in diabetic nephropathy. Nippon Jinzo Gakkai Shi, 38:124-8.

Kaneda H, Hashimoto E, Yatsuji S, et al. 2006. Hyaluronic acid levels can predict severe fibrosis and platelet counts can predict cirrhosis in patients with nonalcoholic fatty liver disease. $J$ Gastroenterol Hepatol, $21: 1459-65$

Katavetin P, Eiam-Ong S and Suwanwalaikorn S. 2006. Pioglitazone reduces urinary protein and urinary transforming growth factor-beta excretion in patients with type 2 diabetes and overt nephropathy. J Med Assoc Thai, 89:170-7.

Kawasaki D, Kosugi K, Waki H, et al. 2007. Role of activated reninangiotensin system in myocardial fibrosis and left ventricular diastolic dysfunction in diabetic patients - reversal by chronic angiotensin II type 1 A receptor blockade. Circ J, 71:524-9.

Khan ZA and Chakrabarti S. 2003. Endothelins in chronic diabetic complications. Can J Physiol Pharmacol, 81:622-34.

Kim NH, Kim KB, Kim DL, et al. 2004. Plasma and urinary vascular endothelial growth factor and diabetic nephropathy in Type 2 diabetes mellitus. Diabet Med, 21:545-51.

Kim Y, Kleppel MM, Butkowski R, et al. 1991. Differential expression of basement membrane collagen chains in diabetic nephropathy. Am J Pathol, 138:413-20

Kiryu K, Morita H, Fujita Y, et al. 1994. Phenotypic expressions of type I, III, IV, V, and VI collagens in patients with diabetic nephropathy: immunohistochemical comparison between HD and non-HD patients. Nippon Jinzo Gakkai Shi, 36:365-73.

Kobayashi T, Inoue T, Okada H, et al. 2005. Connective tissue growth factor mediates the profibrotic effects of transforming growth factor-beta produced by tubular epithelial cells in response to high glucose. Clin Exp Nephrol, 9:114-21.

Kohno M, Horio T, Ikeda M, et al. 1992. Angiotensin II stimulates endothelin-1 secretion in cultured rat mesangial cells. Kidney Int, 42:860-6.

Kohno M, Ikeda M, Johchi M, et al. 1993. Interaction of PDGF and natriuretic peptides on mesangial cell proliferation and endothelin secretion. Am J Physiol, 265:E673-9.

Koitabashi N, Arai M, Kogure S, et al. 2007. Increased connective tissue growth factor relative to brain natriuretic peptide as a determinant of myocardial fibrosis. Hypertension, 49:1120-7.

Kolm V, Sauer U, Olgemooller B, et al. 1996. High glucose-induced TGFbeta 1 regulates mesangial production of heparan sulfate proteoglycan. Am J Physiol, 270:F812-21.

Kotajima N, Kanda T, Yuuki N, et al. 2001. Type IV collagen serum and vitreous fluid levels in patients with diabetic retinopathy. $J$ Int Med Res, 29:292-6.

Kotajima N, Kimura T, Kanda T, et al. 2000. Type IV collagen as an early marker for diabetic nephropathy in non-insulin-dependent diabetes mellitus. J Diabetes Complications, 14:13-7.

Kuiper EJ, Witmer AN, Klaassen I, et al. 2004. Differential expression of connective tissue growth factor in microglia and pericytes in the human diabetic retina. Br J Ophthalmol, 88:1082-7.

Lam S, van der Geest RN, Verhagen NA, et al. 2004. Secretion of collagen type IV by human renal fibroblasts is increased by high glucose via a TGF-beta-independent pathway. Nephrol Dial Transplant, 19:1694-701.

Lam S, van der Geest RN, Verhagen NA, et al. 2003. Connective tissue growth factor and igf-I are produced by human renal fibroblasts and cooperate in the induction of collagen production by high glucose. Diabetes, 52:2975-83.

Laviades C, Varo N, Fernandez J, et al. 1998. Abnormalities of the extracellular degradation of collagen type I in essential hypertension. Circulation, 98:535-40.

Lee HB and Ha H. 2005. Plasminogen activator inhibitor-1 and diabetic nephropathy. Nephrology (Carlton), 10(Suppl):S11-3. 
Lee SW, Song KE, Shin DS, et al. 2005. Alterations in peripheral blood levels of TIMP-1, MMP-2, and MMP-9 in patients with type-2 diabetes. Diabetes Res Clin Pract, 69:175-9.

Lee TS, Saltsman KA, Ohashi H, et al. 1989. Activation of protein kinase $\mathrm{C}$ by elevation of glucose concentration: proposal for a mechanism in the development of diabetic vascular complications. Proc Natl Acad Sci, USA, 86:5141-5.

Lembach KJ. 1976. Induction of human fibroblast proliferation by epidermal growth factor (EGF): enhancement by an EGF-binding arginine esterase and by ascorbate. Proc Natl Acad Sci, USA, 73:183-7.

Li M, Chen Y, Zhang Z, et al. 1999. Inhibition of mesangial cell proliferation by antisense oligodeoxynucleotide targeting preproendothelin-1 mRNA in vitro. Chin Med J (Engl), 112:790-3.

Li YY, Feldman AM, Sun Y, et al. 1998. Differential expression of tissue inhibitors of metalloproteinases in the failing human heart. Circulation, 98:1728-34.

Lindsay MM, Maxwell P and Dunn FG. 2002. TIMP-1: a marker of left ventricular diastolic dysfunction and fibrosis in hypertension. Hypertension, 40:136-41.

Lip PL, Belgore F, Blann AD, et al. 2000. Plasma VEGF and soluble VEGF receptor FLT-1 in proliferative retinopathy: relationship to endothelial dysfunction and laser treatment. Invest Ophthalmol Vis Sci, 41:2115-9.

Lip PL, Chatterjee S, Caine GJ, et al. 2004. Plasma vascular endothelial growth factor, angiopoietin-2, and soluble angiopoietin receptor tie-2 in diabetic retinopathy: effects of laser photocoagulation and angiotensin receptor blockade. Br J Ophthalmol, 88:1543-6.

Li-Saw-Hee FL, Edmunds E, Blann AD, et al. 2000. Matrix metalloproteinase-9 and tissue inhibitor metalloproteinase-1 levels in essential hypertension. Relationship to left ventricular mass and anti-hypertensive therapy. Int J Cardiol, 75:43-7.

Liu X, Luo F, Pan K, et al. 2007. High glucose upregulates connective tissue growth factor expression in human vascular smooth muscle cells. BMC Cell Biol, 8:1.

Liu Y, Wang Z, Yin W, et al. 2007. Severe insulin resistance and moderate glomerulosclerosis in a minipig model induced by high-fat/ highsucrose/ high-cholesterol diet. Exp Anim, 56:11-20.

Ljubimov AV, Burgeson RE, Butkowski RJ, et al. 1996. Basement membrane abnormalities in human eyes with diabetic retinopathy. $J$ Histochem Cytochem, 44:1469-79.

Lorenzi M and Gerhardinger C. 2001. Early cellular and molecular changes induced by diabetes in the retina. Diabetologia, 44:791-804.

$\mathrm{Lu} \mathrm{CH,} \mathrm{Lu} \mathrm{JX,} \mathrm{Hua} \mathrm{GP,} \mathrm{et} \mathrm{al.} \mathrm{2007.} \mathrm{[Effects} \mathrm{of} \mathrm{antisense} \mathrm{RNA} \mathrm{of} \mathrm{connective}$ tissue growth factor expressing plasmid on rat liver fibrosis]. Zhonghua Gan Zang Bing Za Zhi, 15:118-21.

Makino H, Kashihara N, Sugiyama H, et al. 1995. Phenotypic changes of the mesangium in diabetic nephropathy. J Diabetes Complications, 9:282-4.

Makino H, Shikata K, Wieslander J, et al. 1994. Localization of fibril/microfibril and basement membrane collagens in diabetic glomerulosclerosis in type 2 diabetes. Diabet Med, 11:304-11.

Makino H, Yamasaki Y, Haramoto T, et al. 1993. Ultrastructural changes of extracellular matrices in diabetic nephropathy revealed by high resolution scanning and immunoelectron microscopy. Lab Invest, 68:45-55.

Marx N, Froehlich J, Siam L, et al. 2003. Antidiabetic PPAR gammaactivator rosiglitazone reduces MMP-9 serum levels in type 2 diabetic patients with coronary artery disease. Arterioscler Thromb Vasc Biol, 23:283-8.

Mason RM and Wahab NA. 2003. Extracellular matrix metabolism in diabetic nephropathy. J Am Soc Nephrol, 14:1358-73.

Mathews MK, Merges C, McLeod DS, et al. 1997. Vascular endothelial growth factor and vascular permeability changes in human diabetic retinopathy. Invest Ophthalmol Vis Sci, 38:2729-41.

Matos JP, de Lourdes Rodrigues M, Ismerim VL, et al. 2005. Effects of dual blockade of the renin angiotensin system in hypertensive type 2 diabetic patients with nephropathy. Clin Nephrol, 64:180-9.
Maxwell PR, Timms PM, Chandran S, et al. 2001. Peripheral blood level alterations of TIMP-1, MMP-2 and MMP-9 in patients with type 1 diabetes. Diabet Med, 18:777-80.

McClain DA, Paterson AJ, Roos MD, et al. 1992. Glucose and glucosamine regulate growth factor gene expression in vascular smooth muscle cells. Proc Natl Acad Sci, USA, 89:8150-4.

McLennan SV, Fisher E, Martell SY, et al. 2000. Effects of glucose on matrix metalloproteinase and plasmin activities in mesangial cells: possible role in diabetic nephropathy. Kidney Int Suppl, 77:S81-7.

McLennan SV, Wang XY, Moreno V, et al. 2004. Connective tissue growth factor mediates high glucose effects on matrix degradation through tissue inhibitor of matrix metalloproteinase type 1: implications for diabetic nephropathy. Endocrinology, 145:5646-55.

McLennan SV, Yue DK and Turtle JR. 1998. Effect of glucose on matrix metalloproteinase activity in mesangial cells. Nephron, 79:293-8.

Migdalis IN, Kalogeropoulou K, Zachariadis D, et al. 1994. Serum levels of type III procollagen peptide and peripheral vascular disease in diabetic patients. Diabetes Res Clin Pract, 23:179-82.

Morgan K, Wharton J, Webb JC, et al. 1994. Co-expression of reninangiotensin system component genes in human atrial tissue. J Hypertens Suppl, 12:S11-9.

Moriya T, Groppoli TJ, Kim Y, et al. 2001. Quantitative immunoelectron microscopy of type VI collagen in glomeruli in type I diabetic patients. Kidney Int, 59:317-23.

Murphy M, Godson C, Cannon S, et al. 1999. Suppression subtractive hybridization identifies high glucose levels as a stimulus for expression of connective tissue growth factor and other genes in human mesangial cells. J Biol Chem, 274:5830-4.

Naftilan AJ, Pratt RE and Dzau VJ. 1989. Induction of platelet-derived growth factor A-chain and c-myc gene expressions by angiotensin II in cultured rat vascular smooth muscle cells. J Clin Invest, 83:1419-24.

Nahman NS, Jr., Leonhart KL, Cosio FG, et al. 1992. Effects of high glucose on cellular proliferation and fibronectin production by cultured human mesangial cells. Kidney Int, 41:396-402.

Nakamura T, Fukui M, Ebihara I, et al. 1994. Abnormal gene expression of matrix metalloproteinases and their inhibitor in glomeruli from diabetic rats. Ren Physiol Biochem, 17:316-25.

Nakamura T, Matsuda T, Suzuki Y, et al. 2003. Effects of low-density lipoprotein apheresis on plasma matrix metalloproteinase- 9 and serum tissue inhibitor of metalloproteinase-1 levels in diabetic hemodialysis patients with arteriosclerosis obliterans. Asaio J, 49:430-4.

Nakamura T, Ushiyama C, Suzuki S, et al. 2000. Urinary excretion of podocytes in patients with diabetic nephropathy. Nephrol Dial Transplant, 15:1379-83.

Nakashima Y, Fujii H, Sumiyoshi S, et al. 2007. Early human atherosclerosis: accumulation of lipid and proteoglycans in intimal thickenings followed by macrophage infiltration. Arterioscler Thromb Vasc Biol, 27:1159-65.

Nerlich A and Schleicher E. 1991. Immunohistochemical localization of extracellular matrix components in human diabetic glomerular lesions. Am J Pathol, 139:889-99.

Nguyen TQ, Tarnow L, Andersen S, et al. 2006. Urinary connective tissue growth factor excretion correlates with clinical markers of renal disease in a large population of type 1 diabetic patients with diabetic nephropathy. Diabetes Care, 29:83-8.

Nieuwdorp M, Holleman F, de Groot E, et al. 2007. Perturbation of hyaluronan metabolism predisposes patients with type 1 diabetes mellitus to atherosclerosis. Diabetologia, 50:1288-93.

Noji Y, Kajinami K, Kawashiri MA, et al. 2001. Circulating matrix metalloproteinases and their inhibitors in premature coronary atherosclerosis. Clin Chem Lab Med, 39:380-4.

Nunoda S, Genda A, Sugihara N, et al. 1985. Quantitative approach to the histopathology of the biopsied right ventricular myocardium in patients with diabetes mellitus. Heart Vessels, 1:43-7.

Oberhammer FA, Pavelka M, Sharma S, et al. 1992. Induction of apoptosis in cultured hepatocytes and in regressing liver by transforming growth factor beta 1. Proc Natl Acad Sci, USA, 89:5408-12. 
Okazaki R, Matsuoka K, Horiuchi A, et al. 1988. Assays of serum laminin and type III procollagen peptide for monitoring the clinical course of diabetic microangiopathy. Diabetes Res Clin Pract, 5:163-70.

Olgemoller B and Schleicher E. 1993. Alterations of glomerular matrix proteins in the pathogenesis of diabetic nephropathy. Clin Investig, 71:S13-9.

Otani A, Takagi H, Oh H, et al. 2000. Angiotensin II-stimulated vascular endothelial growth factor expression in bovine retinal pericytes. Invest Ophthalmol Vis Sci, 41:1192-9.

Pandolfi A, Cetrullo D, Polishuck R, et al. 2001. Plasminogen activator inhibitor type 1 is increased in the arterial wall of type II diabetic subjects. Arterioscler Thromb Vasc Biol, 21:1378-82.

Paradis V, Perlemuter G, Bonvoust F, et al. 2001. High glucose and hyperinsulinemia stimulate connective tissue growth factor expression: a potential mechanism involved in progression to fibrosis in nonalcoholic steatohepatitis. Hepatology, 34:738-44.

Park IS, Kiyomoto H, Abboud SL, et al. 1997. Expression of transforming growth factor-beta and type IV collagen in early streptozotocin-induced diabetes. Diabetes, 46:473-80.

Park JY, Takahara N, Gabriele A, et al. 2000. Induction of endothelin-1 expression by glucose: an effect of protein kinase C activation. Diabetes, 49:1239-48.

Paueksakon P, Revelo MP, Ma LJ, et al. 2002. Microangiopathic injury and augmented PAI-1 in human diabetic nephropathy. Kidney Int, 61:2142-8.

Paul M, Wagner J and Dzau VJ. 1993. Gene expression of the reninangiotensin system in human tissues. Quantitative analysis by the polymerase chain reaction. J Clin Invest, 91:2058-64.

Pfeiffer A, Middelberg-Bisping K, Drewes C, et al. 1996. Elevated plasma levels of transforming growth factor-beta 1 in NIDDM. Diabetes Care, 19:1113-7.

Praga M, Andrade CF, Luno J, et al. 2003. Antiproteinuric efficacy of losartan in comparison with amlodipine in non-diabetic proteinuric renal diseases: a double-blind, randomized clinical trial. Nephrol Dial Transplant, 18:1806-13.

Qi W, Twigg S, Chen X, et al. 2005. Integrated actions of transforming growth factor-beta1 and connective tissue growth factor in renal fibrosis. Am J Physiol Renal Physiol, 288:F800-9.

Querejeta R, Lopez B, Gonzalez A, et al. 2004. Increased collagen type I synthesis in patients with heart failure of hypertensive origin: relation to myocardial fibrosis. Circulation, 110:1263-8.

Querejeta R, Varo N, Lopez B, et al. 2000. Serum carboxy-terminal propeptide of procollagen type I is a marker of myocardial fibrosis in hypertensive heart disease. Circulation, 101:1729-35.

Rachfal AW and Brigstock DR. 2003. Connective tissue growth factor (CTGF/CCN2) in hepatic fibrosis. Hepatol Res, 26:1-9.

Ratziu V, Bonyhay L, Di Martino V, et al. 2002. Survival, liver failure, and hepatocellular carcinoma in obesity-related cryptogenic cirrhosis. Hepatology, 35:1485-93.

Ratziu V, Giral P, Charlotte F, et al. 2000. Liver fibrosis in overweight patients. Gastroenterology, 118:1117-23.

Razzaque MS, Koji T, Harada T, et al. 1997. Identification of type VI collagen synthesizing cells in human diabetic glomerulosclerosis using renal biopsy sections. Anal Cell Pathol, 15:175-81.

Razzaque MS, Koji T, Taguchi T, et al. 1994. In situ localization of type III and type IV collagen-expressing cells in human diabetic nephropathy. J Pathol, 174:131-8.

Regan TJ, Lyons MM, Ahmed SS, et al. 1977. Evidence for cardiomyopathy in familial diabetes mellitus. $J$ Clin Invest, 60:884-99.

Riser BL, Cortes P, DeNichilo M, et al. 2003. Urinary CCN2 (CTGF) as a possible predictor of diabetic nephropathy: preliminary report. Kidney Int, 64:451-8.

Riser BL, Cortes P, Yee J, et al. 1998. Mechanical strain- and high glucoseinduced alterations in mesangial cell collagen metabolism: role of TGF-beta. J Am Soc Nephrol, 9:827-36.

Riser BL, Denichilo M, Cortes P, et al. 2000. Regulation of connective tissue growth factor activity in cultured rat mesangial cells and its expression in experimental diabetic glomerulosclerosis. $J$ Am Soc Nephrol, 11:25-38.
Risteli J and Risteli L. 1995. Analysing connective tissue metabolites in human serum. Biochemical, physiological and methodological aspects. J Hepatol, 22:77-81.

Roberts AB, Sporn MB, Assoian RK, et al. 1986. Transforming growth factor type beta: rapid induction of fibrosis and angiogenesis in vivo and stimulation of collagen formation in vitro. Proc Natl Acad Sci, USA, 83:4167-71

Roestenberg P, van Nieuwenhoven FA, Joles JA, et al. 2006. Temporal expression profile and distribution pattern indicate a role of connective tissue growth factor (CTGF/CCN-2) in diabetic nephropathy in mice Am J Physiol Renal Physiol, 290:F1344-54.

Roestenberg P, van Nieuwenhoven FA, Wieten L, et al. 2004. Connective tissue growth factor is increased in plasma of type 1 diabetic patients with nephropathy. Diabetes Care, 27:1164-70.

Roth S, Michel K and Gressner AM. 1998. (Latent) transforming growth factor beta in liver parenchymal cells, its injury-dependent release, and paracrine effects on rat hepatic stellate cells. Hepatology, 27:1003-12

Roy S, Maiello M and Lorenzi M. 1994. Increased expression of basement membrane collagen in human diabetic retinopathy. J Clin Invest, 93:438-42.

Roy S, Sala R, Cagliero E, et al. 1990. Overexpression of fibronectin induced by diabetes or high glucose: phenomenon with a memory. Proc Natl Acad Sci, USA, 87:404-8.

Roy S, Sato T, Paryani G, et al. 2003. Downregulation of fibronectin overexpression reduces basement membrane thickening and vascular lesions in retinas of galactose-fed rats. Diabetes, 52:1229-34.

Ruiz-Ortega M, Bustos C, Hernandez-Presa MA, et al. 1998. Angiotensin II participates in mononuclear cell recruitment in experimental immune complex nephritis through nuclear factor-kappa B activation and monocyte chemoattractant protein-1 synthesis. J Immunol, 161:430-9.

Ruiz-Ortega M, Gomez-Garre D, Alcazar R, et al. 1994. Involvement of angiotensin II and endothelin in matrix protein production and renal sclerosis. J Hypertens Suppl, 12:S51-8.

Ruiz-Ortega M, Gonzalez S, Seron D, et al. 1995. ACE inhibition reduces proteinuria, glomerular lesions and extracellular matrix production in a normotensive rat model of immune complex nephritis. Kidney Int, 48:1778-91.

Ruiz-Ruiz FJ, Ruiz-Laiglesia FJ, Samperiz-Legarre P, et al. 2007. Propeptide of procollagen type I (PIP) and outcomes in decompensated heart failure. Eur J Intern Med, 18:129-34.

Ruperez M, Lorenzo O, Blanco-Colio LM, et al. 2003a. Connective tissue growth factor is a mediator of angiotensin II-induced fibrosis. Circulation, 108:1499-505.

Ruperez M, Ruiz-Ortega M, Esteban V, et al. 2003b. Angiotensin II increases connective tissue growth factor in the kidney. Am J Pathol, 163:1937-47

Rutschow S, Li J, Schultheiss HP, et al. 2006. Myocardial proteases and matrix remodeling in inflammatory heart disease. Cardiovasc Res, 69:646-56.

Sakugawa H, Nakayoshi T, Kobashigawa K, et al. 2005. Clinical usefulness of biochemical markers of liver fibrosis in patients with nonalcoholic fatty liver disease. World J Gastroenterol, 11:255-9.

Sanyal AJ. 2002. AGA technical review on nonalcoholic fatty liver disease. Gastroenterology, 123:1705-25.

Sato A, Hayashi K, Naruse M, et al. 2003. Effectiveness of aldosterone blockade in patients with diabetic nephropathy. Hypertension, 41:64-8.

Schaefer L, Raslik I, Grone HJ, et al. 2001. Small proteoglycans in human diabetic nephropathy: discrepancy between glomerular expression and protein accumulation of decorin, biglycan, lumican, and fibromodulin. Faseb J, 15:559-61.

Scheinman JI, Fish AJ and Michael AF. 1974. The immunohistopathology of glomerular antigens. The glomerular basement membrane, collagen, and actomyosin antigens in normal and diseased kidneys. J Clin Invest, $54: 1144-54$. 
Schjoedt KJ, Rossing K, Juhl TR, et al. 2006. Beneficial impact of spironolactone on nephrotic range albuminuria in diabetic nephropathy. Kidney Int, 70:536-42.

Schneeberger SA, Hjelmeland LM, Tucker RP, et al. 1997. Vascular endothelial growth factor and fibroblast growth factor 5 are colocalized in vascular and avascular epiretinal membranes. Am J Ophthalmol, 124:447-54

Schwartzkopff B, Fassbach M, Pelzer B, et al. 2002. Elevated serum markers of collagen degradation in patients with mild to moderate dilated cardiomyopathy. Eur J Heart Fail, 4:439-4.

Shankland SJ, Ly H, Thai K, et al. 1996. Glomerular expression of tissue inhibitor of metalloproteinase (TIMP-1) in normal and diabetic rats. J Am Soc Nephrol, 7:97-104.

Sharma K, Eltayeb BO, McGowan TA, et al. 1999. Captopril-induced reduction of serum levels of transforming growth factor-beta1 correlates with long-term renoprotection in insulin-dependent diabetic patients. Am J Kidney Dis, 34:818-23.

Sharma K, Jin Y, Guo J, et al. 1996. Neutralization of TGF-beta by antiTGF-beta antibody attenuates kidney hypertrophy and the enhanced extracellular matrix gene expression in STZ-induced diabetic mice. Diabetes, 45:522-30.

Sharma K and Ziyadeh FN. 1995. Hyperglycemia and diabetic kidney disease. The case for transforming growth factor-beta as a key mediator. Diabetes, 44:1139-46.

Sharma K, Ziyadeh FN, Alzahabi B, et al. 1997. Increased renal production of transforming growth factor-beta1 in patients with type II diabetes. Diabetes, 46:854-9.

Sheetz MJ and King GL. 2002. Molecular understanding of hyperglycemia's adverse effects for diabetic complications. Jama, 288:2579-88.

Shimizu M, Umeda K, Sugihara N, et al. 1993. Collagen remodelling in myocardia of patients with diabetes. J Clin Pathol, 46:32-6.

Shirk RA, Parthasarathy N, San Antonio JD, et al. 2000. Altered dermatan sulfate structure and reduced heparin cofactor II-stimulating activity of biglycan and decorin from human atherosclerotic plaque. $J$ Biol Chem, 275:18085-92.

Singh R, Alavi N, Singh AK, et al. 1999. Role of angiotensin II in glucose-induced inhibition of mesangial matrix degradation. Diabetes, 48:2066-73

Siperstein MD, Unger RH and Madison LL. 1968. Studies of muscle capillary basement membranes in normal subjects, diabetic, and prediabetic patients. J Clin Invest, 47:1973-99.

Song JH, Cha SH, Lee HJ, et al. 2006. Effect of low-dose dual blockade of renin-angiotensin system on urinary TGF-beta in type 2 diabetic patients with advanced kidney disease. Nephrol Dial Transplant, 21:683-9.

Song W and Ergul A. 2006. Type-2 diabetes-induced changes in vascular extracellular matrix gene expression: relation to vessel size. Cardiovasc Diabetol, 5:3.

Spirin KS, Saghizadeh M, Lewin SL, et al. 1999. Basement membrane and growth factor gene expression in normal and diabetic human retinas. Curr Eye Res, 18:490-9.

Stokes MB, Holler S, Cui Y, et al. 2000. Expression of decorin, biglycan, and collagen type I in human renal fibrosing disease. Kidney Int, 57:487-98.

Sugimoto K, Tsuruoka S and Fujimura A. 2002. Renal protective effect of YM598, a selective endothelin ET(A) receptor antagonist, against diabetic nephropathy in OLETF rats. Eur $J$ Pharmacol, 450:183-9.

Sugimoto R, Enjoji M, Kohjima M, et al. 2005. High glucose stimulates hepatic stellate cells to proliferate and to produce collagen through free radical production and activation of mitogen-activated protein kinase. Liver Int, 25:1018-26.

Sundstrom J, Evans JC, Benjamin EJ, et al. 2004. Relations of plasma total TIMP-1 levels to cardiovascular risk factors and echocardiographic measures: the Framingham heart study. Eur Heart J, 25:1509-16.

Sung SH, Ziyadeh FN, Wang A, et al. 2006. Blockade of vascular endothelial growth factor signaling ameliorates diabetic albuminuria in mice. $J \mathrm{Am}$ Soc Nephrol, 17:3093-104.
Svennevig K, Kolset SO and Bangstad HJ. 2006. Increased syndecan-1 in serum is related to early nephropathy in type 1 diabetes mellitus patients. Diabetologia, 49:2214-6.

Takagi C, Bursell SE, Lin YW, et al. 1996. Regulation of retinal hemodynamics in diabetic rats by increased expression and action of endothelin-1. Invest Ophthalmol Vis Sci, 37:2504-18.

Takahashi M. 1995. Increased urinary fibronectin excretion in type II diabetic patients with microalbuminuria. Nippon Jinzo Gakkai Shi, 37:336-42.

Tashiro H, Shimokawa H, Sadamatu K, et al. 2002. Prognostic significance of plasma concentrations of transforming growth factor-beta in patients with coronary artery disease. Coron Artery Dis, 13:139-43.

Tashiro H, Shimokawa H, Yamamoto K, et al. 1997. Altered plasma levels of cytokines in patients with ischemic heart disease. Coron Artery Dis, 8:143-7.

Tashiro K, Koyanagi I, Ohara I, et al. 2004. Levels of urinary matrix metalloproteinase-9 (MMP-9) and renal injuries in patients with type 2 diabetic nephropathy. J Clin Lab Anal, 18:206-10.

Tayebjee MH, Lim HS, MacFadyen RJ, et al. 2004. Matrix metalloproteinase9 and tissue inhibitor of metalloproteinase- 1 and -2 in type 2 diabetes: effect of 1 year's cardiovascular risk reduction therapy. Diabetes Care, 27:2049-51

Tayebjee MH, Lim HS, Nadar S, et al. 2005a. Tissue inhibitor of metalloproteinse-1 is a marker of diastolic dysfunction using tissue doppler in patients with type 2 diabetes and hypertension. Eur J Clin Invest, $35: 8-12$.

Tayebjee MH, Lip GY, Tan KT, et al. 2005b. Plasma matrix metalloproteinase9, tissue inhibitor of metalloproteinase-2, and CD40 ligand levels in patients with stable coronary artery disease. Am J Cardiol, 96:339-45.

The Diabetes Control and Complications Trial Research Group. 1993. The effect of intensive treatment of diabetes on the development and progression of long-term complications in insulin-dependent diabetes mellitus. N Engl J Med, 329:977-86.

The EUCLID Study Group. 1997. Randomised placebo-controlled trial of lisinopril in normotensive patients with insulin-dependent diabetes and normoalbuminuria or microalbuminuria. Lancet, 349:1787-92.

Thomson S, McLennan SV, Kirwan P, et al. 2007. Renal connective tissue growth factor (CTGF) correlates with glomerular basement membrane thickness and prospective microalbuminuria in a non-human primate model of diabetes: Possible predictive marker for diabetic nephropathy. $J$ Diab Complic, in press.

Thrailkill KM, Bunn RC, Moreau CS, et al. 2007. MMP-2 dysregulation in Type 1 Diabetes Mellitus. Diabetes Care, 30:2321-6.

Tikellis C, Cooper ME, Twigg SM, et al. 2004. Connective tissue growth factor is up-regulated in the diabetic retina: amelioration by angiotensinconverting enzyme inhibition. Endocrinology, 145:860-6.

Timms PM, Wright A, Maxwell P, et al. 2002. Plasma tissue inhibitor of metalloproteinase-1 levels are elevated in essential hypertension and related to left ventricular hypertrophy. Am J Hypertens, 15:269-72.

Tran PK, Agardh HE, Tran-Lundmark K, et al. 2007. Reduced perlecan expression and accumulation in human carotid atherosclerotic lesions. Atherosclerosis, 190:264-70.

Tseng SC, Savion N, Stern R, et al. 1982. Fibroblast growth factor modulates synthesis of collagen in cultured vascular endothelial cells. Eur J Biochem, 122:355-60.

Tsilibary EC. 2003. Microvascular basement membranes in diabetes mellitus. J Pathol, 200:537-46.

Tsutsui H, Matsushima S, Kinugawa S, et al. 2007. Angiotensin II type 1 receptor blocker attenuates myocardial remodeling and preserves diastolic function in diabetic heart. Hypertens Res, 30:439-49.

Twigg SM, Cooper ME. 2004. The time has come to target connective tissue growth factor in diabetic complications. Diabetologia, $47: 965-8$ 
Twigg SM, Cao Z, SV MC, et al. 2002b. Renal connective tissue growth factor induction in experimental diabetes is prevented by aminoguanidine. Endocrinology, 143:4907-15.

Twigg SM, Chen MM, Joly AH, et al. 2001. Advanced glycosylation end products up-regulate connective tissue growth factor (insulin-like growth factor-binding protein-related protein 2) in human fibroblasts: a potential mechanism for expansion of extracellular matrix in diabetes mellitus. Endocrinology, 142:1760-9.

Twigg SM, Joly AH, Chen MM, et al. 2002a. Connective tissue growth factor/IGF-binding protein-related protein-2 is a mediator in the induction of fibronectin by advanced glycosylation end-products in human dermal fibroblasts. Endocrinology, 143:1260-9.

Tyagi SC, Kumar SG, Banks J, et al. 1995. Co-expression of tissue inhibitor and matrix metalloproteinase in myocardium. J Mol Cell Cardiol, 27:2177-89.

UK Prospective Diabetes Study (UKPDS) Group. 1998. Intensive bloodglucose control with sulphonylureas or insulin compared with conventional treatment and risk of complications in patients with type 2 diabetes (UKPDS 33). Lancet, 352:837-53.

Umezono T, Toyoda M, Kato M, et al. 2006. Glomerular expression of CTGF, TGF-beta 1 and type IV collagen in diabetic nephropathy. J Nephrol, 19:751-7.

van den Meiracker AH, Baggen RG, Pauli S, et al. 2006. Spironolactone in type 2 diabetic nephropathy: Effects on proteinuria, blood pressure and renal function. J Hypertens, 24:2285-92.

van Hoeven KH and Factor SM. 1990. A comparison of the pathological spectrum of hypertensive, diabetic, and hypertensive-diabetic heart disease. Circulation, 82:848-55.

Vaughan DE. 2005. PAI-1 and atherothrombosis. J Thromb Haemost, 3:1879-83.

Vranes D, Cooper ME and Dilley RJ. 1999. Cellular mechanisms of diabetic vascular hypertrophy. Microvasc Res, 57:8-18.

Wagner J, Jan Danser AH, Derkx FH, et al. 1996. Demonstration of renin mRNA, angiotensinogen mRNA, and angiotensin converting enzyme mRNA expression in the human eye: evidence for an intraocular reninangiotensin system. Br J Ophthalmol, 80:159-63.

Wahab NA, Harper K and Mason RM. 1996. Expression of extracellular matrix molecules in human mesangial cells in response to prolonged hyperglycaemia. Biochem J, 316 ( Pt 3):985-92.

Wahab NA, Schaefer L, Weston BS, et al. 2005. Glomerular expression of thrombospondin-1, transforming growth factor beta and connective tissue growth factor at different stages of diabetic nephropathy and their interdependent roles in mesangial response to diabetic stimuli. Diabetologia, 48:2650-60.

Wahab NA, Yevdokimova N, Weston BS, et al. 2001. Role of connective tissue growth factor in the pathogenesis of diabetic nephropathy. Biochem J, 359:77-87.

Watanabe H, Sanada H, Shigetomi S, et al. 2000. Urinary excretion of type IV collagen as a specific indicator of the progression of diabetic nephropathy. Nephron, 86:27-35.

Watanabe T, Negishi K, Katayama S, et al. 1991. Serum or urinary concentration of type IV collagen in diabetics. J Diabet Complications, 5:191-2.

Weber KT. 1997. Extracellular matrix remodeling in heart failure: a role for de novo angiotensin II generation. Circulation, 96:4065-82.

Wells JA, Murthy R, Chibber R, et al. 1996. Levels of vascular endothelial growth factor are elevated in the vitreous of patients with subretinal neovascularisation. Br J Ophthalmol, 80:363-6.

Westermann D, Rutschow S, Jager S, et al. 2007. Contributions of inflammation and cardiac matrix metalloproteinase activity to cardiac failure in diabetic cardiomyopathy: the role of angiotensin type 1 receptor antagonism. Diabetes, 56:641-6.

Weston BS, Wahab NA and Mason RM. 2003. CTGF mediates TGFbeta-induced fibronectin matrix deposition by upregulating active alpha5beta1 integrin in human mesangial cells. $J$ Am Soc Nephrol, 14:601-10.

Williamson JR, Chang K, Frangos M, et al. 1993. Hyperglycemic pseudohypoxia and diabetic complications. Diabetes, 42:801-13.
Wolkart G, Stessel H, Saad Z, et al. 2006. Cardioprotective effects of atrasentan, an endothelin-A receptor antagonist, but not of nitric oxide in diabetic mice with myocyte-specific overexpression of endothelial nitric oxide synthase. Br J Pharmacol, 148:671-81.

Woo V, Ni LS, Hak D, et al. 2006. Effects of losartan on urinary secretion of extracellular matrix and their modulators in type 2 diabetes mellitus patients with microalbuminuria. Clin Invest Med, 29:365-72.

Wu LL, Cox A, Roe CJ, et al. 1997. Transforming growth factor beta 1 and renal injury following subtotal nephrectomy in the rat: role of the renin-angiotensin system. Kidney Int, 51:1553-67.

Xu X, Wu Z, Zhou Q, et al. 2002. The role of determining the levels of serum collagen type IV in diagnosing early diabetic nephropathy. Ren Fail, 24:747-53.

Yagame M, Kim Y, Zhu D, et al. 1995. Differential distribution of type IV collagen chains in patients with diabetic nephropathy in non-insulindependent diabetes mellitus. Nephron, 70:42-8.

Yamamoto T, Nakamura T, Noble NA, et al. 1993. Expression of transforming growth factor beta is elevated in human and experimental diabetic nephropathy. Proc Natl Acad Sci, USA, 90:1814-8.

Yang C, Patel K, Harding P, et al. 2007. Regulation of TGF-beta1/MAPKmediated PAI-1 gene expression by the actin cytoskeleton in human mesangial cells. Exp Cell Res, 313:1240-50.

Yano Y, Ura H, Gabazza EC, et al. 1998. Circulating levels of 7 S domain of type IV collagen and atrial natriuretic peptide in normotensive type 2 diabetic patients with or without retinopathy. Horm Metab Res, 30:103-7.

Yano Y, Ura H, Sumida Y, et al. 1997. Serum 7S domain of type IV collagen levels in essential hypertension and hypertensive type 2 diabetic patients. Diabet Med, 14:466-71.

Yokota T, Ma RC, Park JY, et al. 2003. Role of protein kinase C on the expression of platelet-derived growth factor and endothelin-1 in the retina of diabetic rats and cultured retinal capillary pericytes. Diabetes, 52:838-45.

Yoneda M, Mawatari H, Fujita K, et al. 2007. Type IV collagen 7s domain is an independent clinical marker of the severity of fibrosis in patients with nonalcoholic steatohepatitis before the cirrhotic stage. J Gastroenterol, 42:375-81.

Zannad F, Alla F, Dousset B, et al. 2000. Limitation of excessive extracellular matrix turnover may contribute to survival benefit of spironolactone therapy in patients with congestive heart failure: insights from the randomized aldactone evaluation study (RALES). Rales Investigators. Circulation, 102:2700-6.

Zaoui P, Cantin JF, Alimardani-Bessette M, et al. 2000. Role of metalloproteases and inhibitors in the occurrence and progression of diabetic renal lesions. Diabetes Metab, 26(Suppl 4):25-9.

Zhang BB, Cai WM, Weng HL, et al. 2003. Diagnostic value of platelet derived growth factor-BB, transforming growth factor-beta1, matrix metalloproteinase-1, and tissue inhibitor of matrix metalloproteinase-1 in serum and peripheral blood mononuclear cells for hepatic fibrosis. World J Gastroenterol, 9:2490-6.

Zhou G, Li C and Cai L. 2004. Advanced glycation end-products induce connective tissue growth factor-mediated renal fibrosis predominantly through transforming growth factor beta-independent pathway. Am J Pathol, 165:2033-43.

Zhu D, Kim Y, Steffes MW, et al. 1994. Glomerular distribution of type IV collagen in diabetes by high resolution quantitative immunochemistry. Kidney Int, 45:425-33

Zimmet P. 2000. Globalization, coca-colonization and the chronic disease epidemic: can the Doomsday scenario be averted? J Intern Med, 247:301-10.

Ziyadeh FN, Han DC, Cohen JA, et al. 1998. Glycated albumin stimulates fibronectin gene expression in glomerular mesangial cells: involvement of the transforming growth factor-beta system. Kidney Int, 53:631-8.

Ziyadeh FN, Hoffman BB, Han DC, et al. 2000. Long-term prevention of renal insufficiency, excess matrix gene expression, and glomerular mesangial matrix expansion by treatment with monoclonal antitransforming growth factor-beta antibody in $\mathrm{db} / \mathrm{db}$ diabetic mice. Proc Natl Acad Sci, USA, 97:8015-20. 
Ziyadeh FN, Sharma K, Ericksen M, et al. 1994. Stimulation of collagen gene expression and protein synthesis in murine mesangial cells by high glucose is mediated by autocrine activation of transforming growth factor-beta. J Clin Invest, 93:536-42.
Zoja C, Orisio S, Perico N, et al. 1991. Constitutive expression of endothelin gene in cultured human mesangial cells and its modulation by transforming growth factor-beta, thrombin, and a thromboxane A2 analogue. Lab Invest, 64:16-20. 